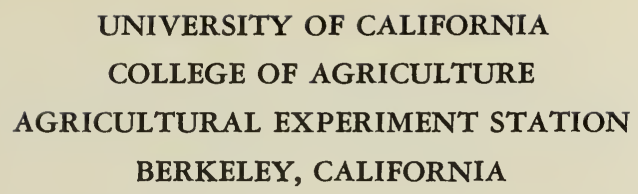

\title{
IRRIGATION EXPERIMENTS WITH PEARS AND APPLES
}

A. H. HENDRICKSON and F. J. VEIHMEYER

\section{BULLETIN 667}

May, 1942 


\section{CONTENTS}

PAGE

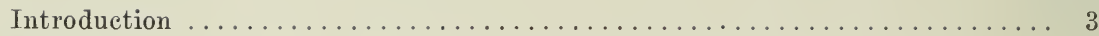

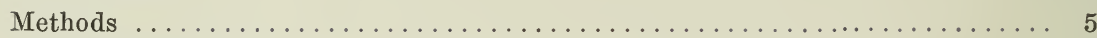

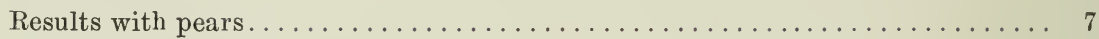

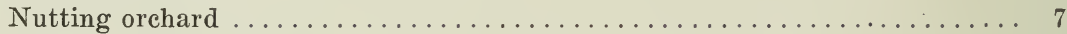

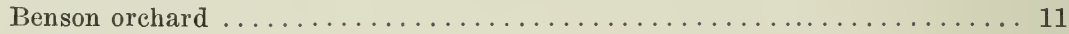

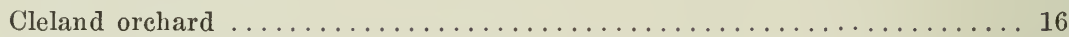

University Farm orchard . . . . . . . . . . . . . . . . . . . 23

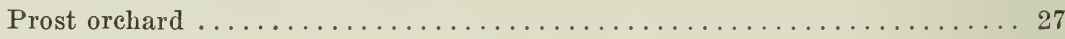

Observations on maturity of pear fruits under dry soil conditions in other

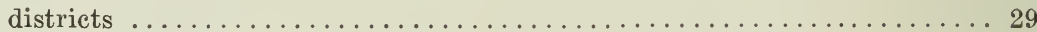

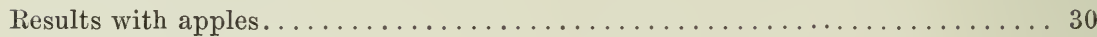

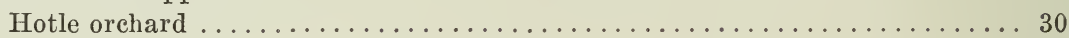

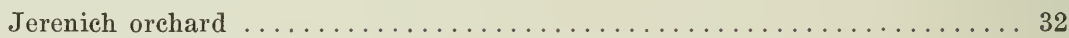

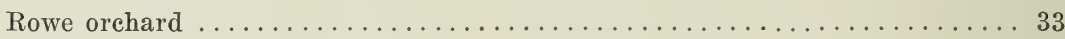

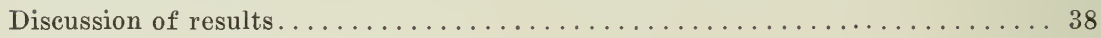

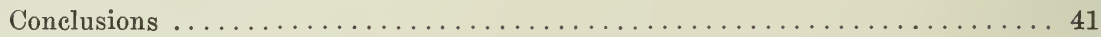

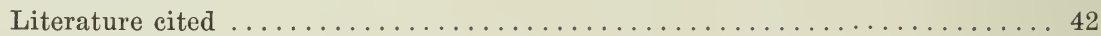




\title{
IRRIGATION EXPERIMENTS WITH PEARS AND APPLES
}

\author{
A. H. HENDRICKSON ${ }^{2}$ AND F. J. VEIHMEYER
}

\section{INTRODUCTION}

Pefars in California are grown under a wide range of climatic conditions, varying from the comparative mildness of the central-coast region to the warmth of the interior valleys and foothills. Apples, for the most part, are grown in the central-coast region, with scattered plantings in many other sections. Climatic conditions in the central-coast region during the growing season are characterized by mild temperatures, usually not above $90^{\circ} \mathrm{F}$, and by high fog that frequently persists until 9 or 10 a.m. during May and June and sometimes into the early part of July. In the interior valley and in Lake and Mendocino counties, where some of these experiments were conducted, the temperatures are higher than in the central-coast region, and there are no morning fogs during the growing season. In general, the amount of water required for transpiration by the trees in the coast region is considerably less than in the interior districts. Winter rainfall, ordinarily, is heavier in the coast region, but in both regions there is little or no rain from April until October or November. The heaviest rains generally occur during November, December, January, and February.

Judging from the literature on the irrigation of pears and apples, comparatively little work has been done with these fruits in recent years. The irrigation of pears and apples has been studied experimentally in the Pacific Northwest, and some reports on the irrigation of apples under eastern conditions have been published by the United States Department of Agriculture.

Aldrich, Lewis, and Work $(1,2,3,4,5,13,14),{ }^{4}$ in papers dealing with the irrigation of Anjou pears, report that the growth of fruit began to slow down before the permanent wilting percentage ${ }^{5}$ was reached, and while there was 60 to 80 per cent available water, or the water between the moisture equivalent and the permanent wilting percentage, left in the soil. Their work was carried on with a shallow, heavy, poorly drained soil classified as Meyer clay adobe. They recommended frequent irrigation to keep the moisture supply above 60 per cent of available

${ }^{1}$ Received for publication April 4, 1941.

${ }^{2}$ Pomologist in the Experiment Station.

${ }^{3}$ Professor of Irrigation and Irrigation Engineer in the Experiment Station.

"Italic numbers in parentheses refer to "Literature Cited" at the end of this paper.

"In this bulletin such terms as "readily available moisture," "permanent wilting percentages," and "moisture equivalent," are used as defined in Extension Circular $50(18)$. 
water in order to maintain a normal rate of growth of fruit. Work (20) stated that "soil moisture becomes less readily available to pear trees as the moisture in the soil declines from the field capacity toward the wilting percentage." Work and Lewis (21) explain the necessity for maintaining the soil moisture at a high level on the basis that (1) "the roots do not seem to occupy the entire soil mass" and (2) "the soil moisture content of the soil in contact with the feeding roots may be at or near the permanent wilting percentage, while at the same time the moisture content at some distance, perhaps only a few millimeters away, may be much higher, thus allowing the average content for an ordinary soil sample to be well above the wilting percentage at the time a tree shows serious distress for water." Aldrich (1) thinks that "specific results such as set of fruit or fruit growth in relation to a definite amount of available moisture can be directly applied only to Anjou trees in shallow clay adobe soil."

Hendrickson and Veihmeyer (12) reported results with Bartlett pears in California on a Dublin clay adobe soil substantially the same as those obtained with pears and with other fruits on medium-textured soils.

Magness, Degman, and Furr (15), working with apples in Maryland, found no reduction in rate of growth of apples until the soil moisture in the driest part of the root zone was near the permanent wilting percentage. In earlier reports, Furr and Degman ( 7 ) and Furr and Magness (8) had concluded that there was a slight slowing down of growth of this fruit while the moisture content was slightly above the wilting percentage.

Boynton (6), working with apples on a shallow soil in the Hudson Valley, found that growth of fruit decreased when the soil moisture in the top 2 feet was decreased to the permanent wilting percentage.

The effect of soil moisture on the quality of the fruit and upon its keeping properties has received considerable attention during the past few years. Haller and Harding (9), working with apples, reported that differences in soil moisture had no effect on susceptibility to decay, but that irrigated apples were softer and showed greater breakdown after removal from storage. They state, however, that "the benefits from the greater yields and higher quality of the apples grown under ample soil moisture far outweigh the detriment of shorter storage life." Ryall and Aldrich (16) and Ryall and Reimer (17) report higher pressure tests and an increased proportion of total solids in pears from unirrigated trees, but the texture and flavor of sound fruit were approximately the same from both treatments when the fruit was in prime eating condition.

The California Agricultural Experiment Station has underway several projects dealing with the irrigation of deciduous fruit trees. The 
results obtained with peaches and prunes have been published $(10,11)$. This report describes similar experiments with pear trees in the centralcoast, north-coast, and Sacramento Valley regions ; and with apples in the central-coast region. Experiments with Bartlett pears were carried on in the E. E. Nutting orchard between Hollister and San Juan Bautista in 1933 and 1934; in the H. W. Benson orchard at Kelseyville in 1935, 1936, and 1937; in the H. O. Cleland orchard in Potter Valley in 1936, 1937, 1938, and 1939; and in the H. G. Prost orchard near Concord in 1939; and with Bartlett and Winter Nelis pears in the University Farm orchard at Davis in 1934, 1935, and 1936. Experiments were carried on with Gravenstein apples in the William Hotle orchard at Sebastopol in 1930; and with Yellow Newtown apples near Watsonville in the Pajaro Valley, in the A. N. Jerenich orchard in 1932, and in the J. H. Rowe orchard in 1933 and 1934.

\section{METHODS}

The various plots of trees used in these experiments were chosen for experimental work in order to secure data from widely separated districts having different climatic conditions and soils of different origins, textures, and water-holding characteristics. They were laid out with the simple objective of studying the growth, maturity, and keeping quality of the fruit when one plot was supplied with readily available soil moisture and another was left unirrigated until certain responses were obtained in appearance of foliage or fruit or until the soil-moisture record showed that water was needed. In other words, one plot was kept continuously supplied with readily available moisture, and the other was allowed to deplete the soil moisture to the permanent wilting percentage during certain periods. Except for a few weeds in some cases, the orchards were essentially clean-cultivated during the summer. In a few cases, the soil moisture in the unirrigated plots did not reach the permanent wilting percentage. As the size of the fruit was expected to be reduced in the dry treatment, it would not have been fair to ask any grower to sacrifice part of the returns from any considerable number of trees. The work, therefore, was carried out in small plots without replications. All experimental trees were surrounded by guards that received the same treatment as the experimental ones.

This type of field experiment proved satisfactory for studying the growth of fruit, the storage qualities, and the maturity as indicated by pressure tests ; also for determining the water-holding properties of the various soils where the experiments were conducted. Reliable results on yields could not be obtained, however, because of the small size of the plots and the relative brevity of each experiment. Yield data from the 
plots at Davis were unsatisfactory some years because of the severity of pear blight.

In every case a stock supply of soil was obtained from the plot with a large auger, the samples being taken in 1-foot depths at from six to eight places in the plot. From this stock supply the moisture equivalents and permanent wilting percentages were ascertained before field work started. The moisture equivalents were found by means of a soil centrifuge, and the wilting percentages by growing and wilting sunflower plants in sealed containers. All soil-moisture percentages are based on the oven-dry weight of the soil.

The moisture equivalent corresponds closely to the field capacity, or the moisture percentage held in the soil after the excess gravitational water has drained away and after the rate of downward movement of water has materially decreased, which usually takes place within 2 or 3 days in pervious soils of uniform structure and texture. The difference between the moisture equivalent and the permanent wilting percentage shows what percentage of moisture is readily available to plants, and the ratio between them is a method of indicating the proportion of moisture that is readily available.

Soil sampling ordinarily was started in April and was continued at one- or two-week intervals throughout the growing season. As soon as several points were secured on a curve, showing how fast the soil moisture was being used in each plot, a suitable irrigation program was planned in coöperation with the owner. The irrigation schedule arranged did not interfere with spraying and harvesting. The soil samples were taken every foot to a depth of 6 feet, and for the 6-to-9-, and 9-to-12-foot depths. All samples were dried 4 days at $105^{\circ} \mathrm{C}$.

There was close agreement between the permanent wilting percentages and the moisture contents at which the moisture-extraction curves became horizontal or nearly so. These lines should not be confused with the relatively short, horizontal portions of the moisture curves that sometimes occurred at comparatively high moisture contents.

The soil-moisture data are graphically shown by plotting the soilmoisture contents, expressed as percentages of the dry weight of soil, against time. One chart for each orchard is given. In cases where the experiments extended over more than one year, the soil-moisture data not shown in the charts are tabulated.

The average soil-moisture contents are indicated by circles on the charts. Straight lines were fitted, by eye, to these points, allowing a tolerance of about 1 per cent of soil moisture. If straight lines connecting several points could not be drawn within this limitation, the indicated moisture contents were connected with lines from point to point. 
Where the positions of the points indicated wide variability in soil texture, the lines were also drawn between consecutive points. This method of drawing the moisture curves as straight lines, within the tolerance previously mentioned, is believed to illustrate more nearly the actual soil-moisture conditions than where the curves are drawn to connect the points. The tolerance of 1 per cent of soil moisture is less than the difference frequently obtained between consecutive individual samples at the same depths.

Growth of the fruit was obtained by measuring the circumferences of 100 specimens in each plot with a steel tape each time the soil samples were taken. The volumes, assuming the fruits to be spherical, were then calculated. Preliminary experiments indicated that comparisons based on volumes so calculated correspond very closely to those based on volumes determined by displacement.

At harvest time, one or two boxes of fruit were obtained in each of two pickings from each plot and taken to Davis for storage tests. On arrival in Davis, usually the day after picking, pressure tests of each lot were taken with a $5 / 16^{-i n c h}$ pressure tester for pears and a $7 / 16^{-i n c h}$ tester for apples. These pressure tests indicate the maturity of the fruit. Each lot of pears and Gravenstein apples was then divided, half being stored at $32^{\circ} \mathrm{F}$ and half at $45^{\circ}$ to $50^{\circ}$. At the end of 2 weeks, the fruit was removed from storage and kept at room temperature, $70^{\circ}$, for ripening. Frequent pressure tests and color comparisons were made during the storage and ripening periods. When fully ripe the various lots were sampled for quality. The Yellow Newtown apples were kept in $36^{\circ}$ storage throughout the storage period and tested at intervals for firmness and for internal browning.

\section{RESULTS WITH PEARS}

Nutting Orchard.-The Bartlett pear trees in the Nutting orchard were on French-pear rootstock, about forty-five years old, planted 20 feet apart, and remarkably uniform and productive. The soil was classified as a Yolo clay loam, medium to heavy in texture in the top 6 feet and sandy in the 6-to-12-foot depth. During the experiment, layers of different kinds of soil not apparent in the regular soil samples were found. These layers made difficult the interpretation of soilmoisture conditions (19). The plots consisted of five adjacent trees surrounded by guard trees that received the same irrigation treatment as the experimental ones. Soil drainage was excellent, at least to a depth of 12 feet. Climatic conditions were mild, with morning fogs frequently persisting until 9 or 10 o'clock. The annual rainfall was between 20 and 25 inches. 


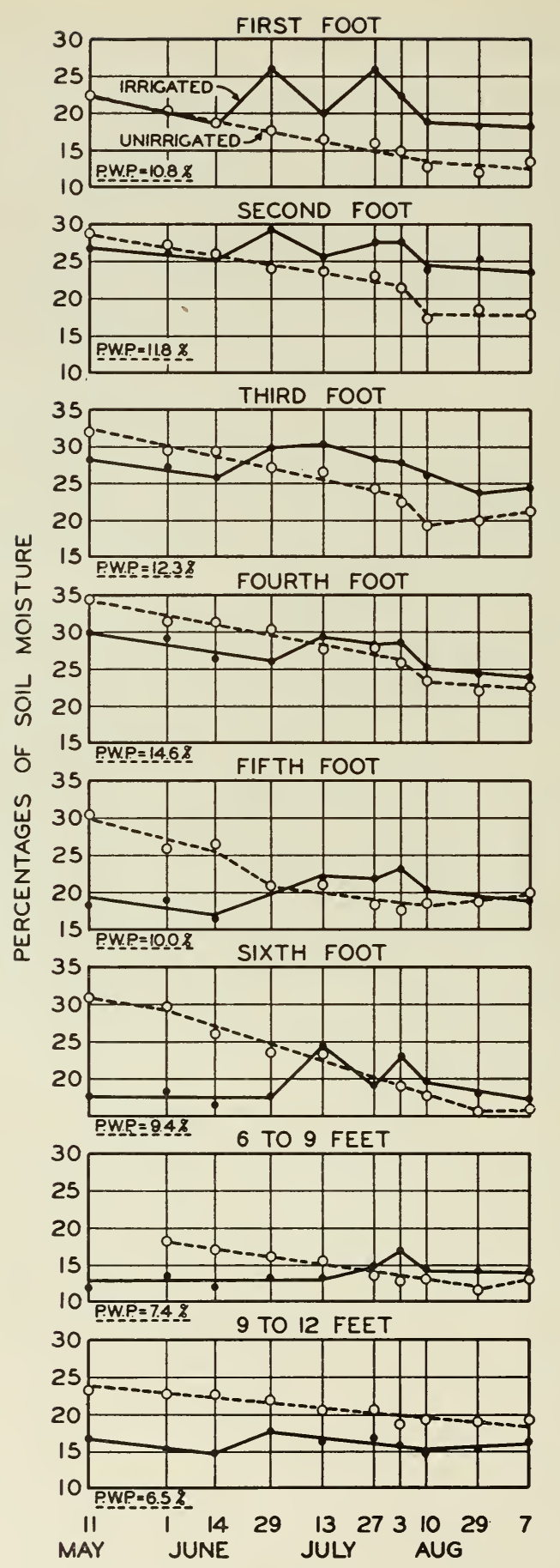

Fig. 1.-Soil-moisture conditions in the Nutting orchard, San Juan Bautista, 1933. The permanent wilting percentage is indicated by the letters P.W.P. The wet plot was irrigated June 27, July 7, and July 23. 
Table 1 gives the soil-moisture characteristics in the Nutting orchard. The ratios between the moisture equivalents and the permanent wilting percentages are fairly high, which indicates that a relatively large proportion of water held by the soil at the moisture equivalent or field capacity is readily available for use by the trees.

Figure 1 gives the soil-moisture record for the Nutting orchard in 1933. As shown by the rather flat slope of the curves, moisture was used

\section{TABLE 1}

Moisture Equivalents and Permanent Wilting Percentages of Yolo Clay Loam SoIl from the Nutting OrChard, SAN JUAN BAUTista

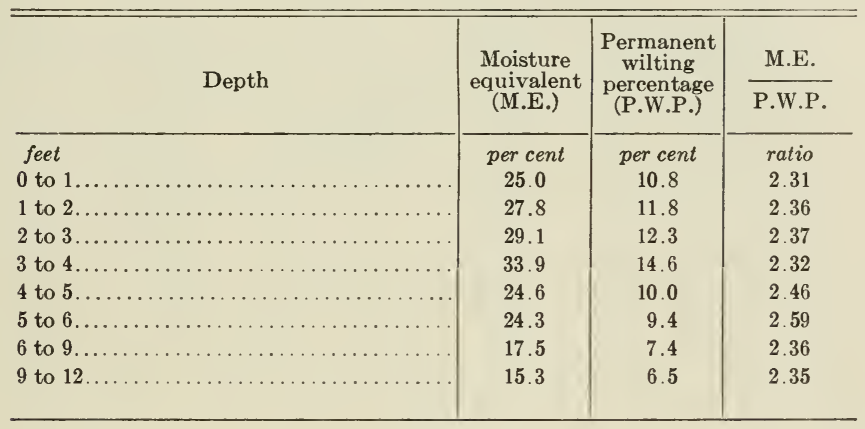

slowly; at no time during the season between May 11 and August 24, when the second picking was made, did the soil moisture in either plot reach the permanent wilting percentage. Furthermore, the covercrop of native weeds, present on both plots and used as indicator plants, showed no wilting even on warm afternoons. The wet plot was given three irrigations. The first was applied on June 27, but only penetrated to a depth of about 3 feet, the second was applied on July 7, and the third on July 23. After each irrigation there was more moisture in the top 3 feet in the wet plot than in the dry. Since several days, sometimes a week or more, elapsed between the times samples were taken before and after irrigation, the curves for the Nutting, as well as the other orchards, do not indicate the moisture conditions during these periods. They do, however, give a general picture of the moisture conditions and show that the irrigated plots were at a much higher moisture level than the unirrigated ones. From early in May until the middle of June, the soilmoisture conditions in the dry plot were higher than in the wet, but thereafter they were higher in the top 3 feet of the wet plot than in the dry, and approximately equal in the second 3 feet. The soil-moisture record for the 6-to-9-foot depth is so erratic, probably owing to the vari- 
ation in soil texture, that no attempt is made to interpret it. Little or no moisture was extracted from the soil in the 9-to-12-foot depth.

In 1934 the soil-moisture results resembled those of 1933. The trees in both plots used water slowly and did not exhaust the readily available supply during the growing season. The wet plot was irrigated on May 9 and on June 15. Table 2 shows the moisture percentages for 1934.

TABLE 2

Average Soll-Moisture Percentages, Nutting Orchard, San Juan Bautista, 1934

\begin{tabular}{l|l|l|l|l|l|l|l|l}
\hline \hline Date & $0-1 \mathrm{ft}$. & $1-2 \mathrm{ft}$. & $2-3 \mathrm{ft}$. & $3-4 \mathrm{ft}$. & $4-5 \mathrm{ft}$. & $5-6 \mathrm{ft}$. & $6-9 \mathrm{ft}$. & $9-12 \mathrm{ft}$. \\
\hline
\end{tabular}

Wet plot*

\begin{tabular}{|c|c|c|c|c|c|c|c|c|}
\hline April 18.. & $\begin{array}{c}\text { per cent } \\
21.1\end{array}$ & $\begin{array}{c}\text { per cent } \\
16.8\end{array}$ & $\begin{array}{c}\text { per cent } \\
18.2\end{array}$ & $\begin{array}{c}\text { per cent } \\
21.8\end{array}$ & $\begin{array}{c}\text { per cent } \\
15.8\end{array}$ & $\begin{array}{c}\text { per cent } \\
13.3\end{array}$ & $\begin{array}{c}\text { per cent } \\
11.9\end{array}$ & $\begin{array}{c}\text { per cent } \\
13.8\end{array}$ \\
\hline May $3 \ldots \ldots \ldots \ldots$ & 12.4 & 16.0 & 17.2 & 19.3 & 15.6 & 12.8 & - & - \\
\hline May $16 \ldots$. & 21.0 & 26.1 & 26.8 & 25.2 & 21.3 & 18.5 & $\longrightarrow$ & - \\
\hline May $31 \ldots \ldots \ldots \ldots$ & 20.0 & 25.4 & 28.6 & 24.5 & 18.7 & 15.0 & - & $\longrightarrow$ \\
\hline June $12 \ldots \ldots \ldots$ & 19.1 & 24.8 & 27.2 & 23.3 & 15.3 & 15.3 & - & - \\
\hline June $28 \ldots \ldots \ldots \ldots$ & 21.1 & 29.2 & 21.0 & 34.0 & 31.1 & 29.5 & - & $\longrightarrow$ \\
\hline July $12 \ldots \ldots \ldots \ldots$ & 16.9 & 25.4 & 29.3 & 31.7 & 28.8 & 27.9 & 17.2 & 13.2 \\
\hline July $25 \ldots \ldots \ldots$ & 16.2 & 24.1 & 28.7 & 29.9 & 27.7 & 28.1 & 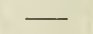 & - \\
\hline August $24 \ldots \ldots \ldots$ & 14.8 & 21.5 & 22.9 & 25.2 & 19.0 & 24.3 & $\longrightarrow$ & - \\
\hline September $21 \ldots$. & 15.2 & 19.8 & 21.2 & 24.1 & 21.5 & 20.8 & $\longrightarrow$ & - \\
\hline October $25 \ldots \ldots$. & 13.9 & 17.8 & 20.0 & 21.8 & 18.9 & 16.0 & 16.0 & 14.8 \\
\hline
\end{tabular}

Dry plot

\begin{tabular}{|c|c|c|c|c|c|c|c|c|}
\hline & per cent & per cent & per cent & per cent & per cent & per cent & per cent & per cent \\
\hline April $18 \ldots \ldots \ldots$ & 12.4 & 16.1 & 25.7 & 22.7 & 13.4 & 12.3 & 12.5 & 18.4 \\
\hline May $3 \ldots$ & 12.3 & 15.0 & 16.4 & 20.2 & 16.4 & 13.4 & & - \\
\hline May $16 \ldots . .$. & 11.6 & 15.9 & 16.9 & 19.4 & 14.1 & 13.3 & & \\
\hline May $31 \ldots$. & 14.4 & 17.6 & 18.3 & 21.5 & 16.4 & 15.6 & & \\
\hline June $12 \ldots \ldots$. & 13.8 & 16.9 & 18.7 & 21.5 & 16.9 & 15.8 & & \\
\hline June $28 \ldots$. & 12.6 & 16.1 & 17.8 & 19.3 & 15.7 & 11.4 & & - \\
\hline July $12 \ldots \ldots \ldots$ & 11.7 & 16.0 & 16.5 & 19.5 & 12.0 & 12.3 & 10.8 & 16.4 \\
\hline July $25 \ldots .$. & 11.4 & 16.5 & 17.6 & 19.9 & 12.1 & 12.6 & & \\
\hline August $24 \ldots . \ldots \ldots$ & 11.7 & 16.4 & 16.9 & 19.1 & 13.2 & 12.3 & & 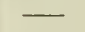 \\
\hline September $21 \ldots$. & 10.2 & 16.0 & 17.1 & 19.8 & 14.1 & 12.8 & & - \\
\hline October $25 \ldots$ & 11.1 & 15.5 & 16.8 & 18.2 & 13.8 & 10.9 & 8.9 & 8.0 \\
\hline
\end{tabular}

* Wet plot irrigated May 9 and June 15 .

The volumes of the measured fruits in 1933 are given in figure 2. Since there were no consistent differences in the growth of the fruits, evidently the trees in both plots secured a supply of water at all times. Results in 1934 were similar. Evidently, therefore, the growth of the fruit was not affected by the differences in soil moisture found under the conditions existing in the Nutting orchard.

At harvest time in 1933, two pickings were made, one on August 10 and the other on August 24. Two boxes of fruit were secured from each plot at each picking and brought to Davis for storage tests. In both pick- 
ings the pressure tests of the fruit from the irrigated plot were slightly but not significantly higher than those from the dry, but these differences disappeared during storage. The fruit stored at $50^{\circ} \mathrm{F}$ and that stored at $32^{\circ}$ kept equally well in storage, and no significant differences were found in subsequent pressure-tests, the color, or the eating quali-

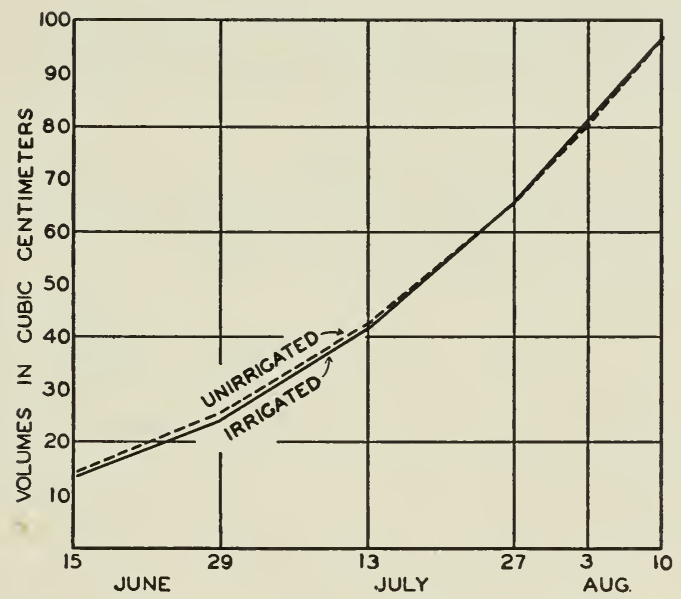

Fig. 2.-Sizes of pears in the Nutting orchard, 1933.

ties. In 1934, when fruit samples were picked on July 20 and 25, similar results were obtained. The initial pressure tests for both years were as follows :

Date picked

August 10, 1933

August 24, 1933

July 20, 1934

July 25, 1934
Pressure test, wet plot, in pounds

16.7

15.4

18.1

17.3
Pressure test, dry plot, in pounds

16.3

14.9

17.1

16.5

Benson Orchard.-The Bartlett pear trees in the Benson orchard were on French-pear rootstock, about thirty years old, planted 24 feet apart, and fairly uniform in size. Except for the irrigation treatment, the cultural operations followed the general practice of the district. The soil, classified as a Dublin clay adobe, contains about 50 per cent clay and exhibits typical adobe structure. This orchard is situated some 2 miles from Clear Lake near Kelseyville at an elevation of perhaps 1,300 feet above sea level. Each spring, during 1935, 1936, and 1937, the water table rose to approximately 4 feet below the surface, but dropped below 6 feet as the season progressed. As far as could be observed, no deleterious results followed. Furthermore, the fruit behaved the same in the dry plot as in the dry plots of other pear orchards where no water table was 
encountered. The plots consisted of four trees each, surrounded on all sides by guards that received the same irrigation treatment as the experimental trees. During the growing season, the climatic conditions were characterized by clear, warm days with maximum temperatures occasionally as high as $100^{\circ} \mathrm{F}$. The average annual rainfall was slightly more than 20 inches.

Table 3 gives the water-holding characteristies of this soil. The soilmoisture record for the 1935 season is shown graphically in figure 3, as

TABLE 3

Moisture Equivalents and Permanent Wilting Percentages of Dublin Clay Adobe Sorl from the Benson

OrChard, Kelseyville

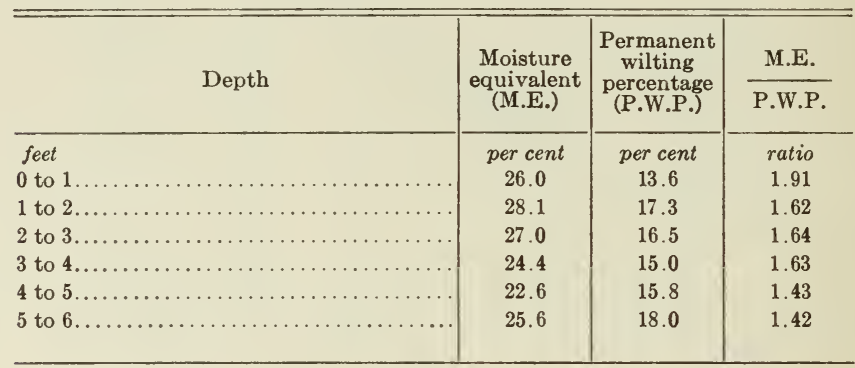

a typical example of the results during the three years of experimental work in this orchard. According to the data for 1935, the soil-moisture conditions were about the same in both plots from the last of April until the last week of June. The wet plot was irrigated on June 27 and on July 24, or shortly after the soil samples were taken in the latter parts of June and July. These irrigations penetrated to a depth of about 4 feet. The dry plot received no irrigation water while the fruit was on the trees. The permanent wilting percentage was reached in the top 4 feet of the dry plot about July 9, as indicated by the flattening of the curves; but there was readily available moisture in the fifth and sixth foot throughout the season. Some water, however, was used from these depths during the season, as shown by the downward slope of the curves. Because of the topography of the region, standing water was encountered at a depth of about 4 feet during the winter and early spring. As the water table gradually receded, the trees were able to reduce the moisture content of the soil in the fifth and sixth foot to a certain extent; but in the dry plot the amount that they thus obtained was apparently not sufficient to keep the fruit growing at a normal rate when the top 4 feet of soil was dry. In this particular orchard the growth of the fruit depended largely upon the moisture in the top 4 feet. 
Figure 4 shows the growth of the fruit in the Benson orchard in 1935. The average sizes between May 14 and June 25 were about the same in both plots; but after the latter date, the fruit grew more slowly in the
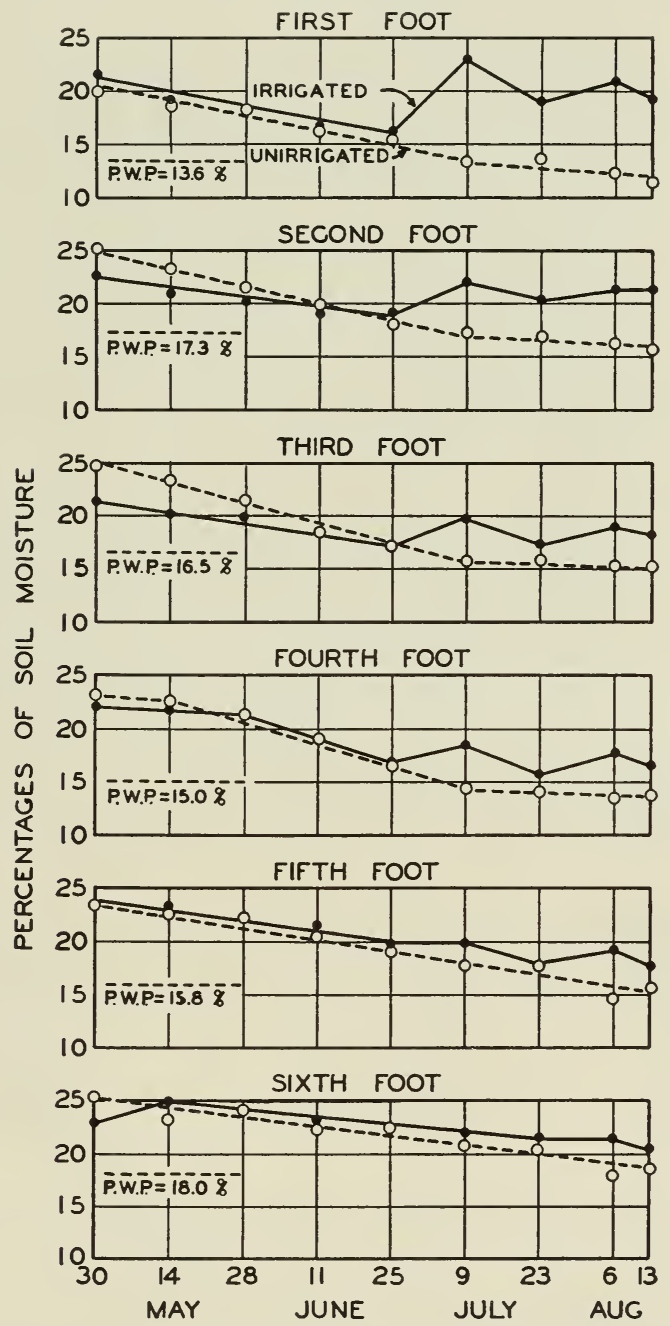

Fig. 3.-Soil-moisture conditions in the Benson orchard, Kelseyville, 1935. The permanent wilting percentage is indicated by the letters P.W.P. The wet plot was irrigated June 27 and July 24.

dry plot than in the wet. The decreased growth in the dry plot oceurred at about the time the moisture content in the top 4 feet reached the permanent wilting percentage.

Table 4 gives the soil-moisture data for the Benson orchard for 1936 and 1937. The wet plot was irrigated on July 3 and July 27 in 1936; on 
TABLE 4

Average Soll-Moisture Percentages, Benson Orchard, Kelseyville, 1936 AND 1937

\begin{tabular}{|c|c|c|c|c|c|c|c|c|c|c|c|c|}
\hline \multirow[b]{2}{*}{ Date } & \multicolumn{6}{|c|}{ Wet plot* } & \multicolumn{6}{|c|}{ Dry plot } \\
\hline & $\begin{array}{l}0-1 \\
\mathrm{ft} .\end{array}$ & $\begin{array}{l}1-2 \\
\mathrm{ft} .\end{array}$ & $\begin{array}{l}2-3 \\
\mathrm{ft} .\end{array}$ & $\begin{array}{l}3-4 \\
\mathrm{ft} .\end{array}$ & $\begin{array}{l}4-5 \\
\text { ft. }\end{array}$ & $\begin{array}{l}5-6 \\
\text { ft. }\end{array}$ & $\begin{array}{l}0-1 \\
\text { ft. }\end{array}$ & $\begin{array}{l}1-2 \\
\text { ft. }\end{array}$ & $\begin{array}{l}2-3 \\
\mathrm{ft} .\end{array}$ & $\begin{array}{l}3-4 \\
\mathrm{ft} .\end{array}$ & $\begin{array}{l}4-5 \\
\text { ft. }\end{array}$ & $\begin{array}{l}5-6 \\
\text { ft. }\end{array}$ \\
\hline 1936: & $\begin{array}{c}\text { per } \\
\text { cent }\end{array}$ & $\begin{array}{c}\text { per } \\
\text { cent }\end{array}$ & $\begin{array}{c}\text { per } \\
c \in n t\end{array}$ & $\begin{array}{c}\text { per } \\
\text { cent }\end{array}$ & $\begin{array}{c}\text { per } \\
\text { cent }\end{array}$ & $\begin{array}{c}p \in r \\
\text { cent }\end{array}$ & $\begin{array}{c}\text { per } \\
\text { cent }\end{array}$ & $\begin{array}{c}\text { per } \\
\text { cent }\end{array}$ & $\begin{array}{c}p \epsilon r \\
\text { cent }\end{array}$ & $\begin{array}{c}\text { per } \\
\text { cent }\end{array}$ & $\begin{array}{c}\text { per } \\
\text { cent }\end{array}$ & $\begin{array}{c}\text { per } \\
\text { cent }\end{array}$ \\
\hline April 28. & 19.3 & 19.8 & 19.8 & 20.8 & 21.9 & 23.0 & 19.1 & 23.9 & 22.8 & 20.5 & 21.4 & 23.0 \\
\hline May $12 \ldots$ & 26.3 & 20.4 & 18.5 & 19.9 & 22.7 & 22.3 & 25.2 & 24.3 & 22.4 & 21.5 & 21.8 & 21.8 \\
\hline May 26 . & 22.1 & 18.3 & 17.0 & 19.3 & 21.8 & 23.5 & 22.5 & 22.7 & 21.6 & 20.9 & 21.9 & 24.5 \\
\hline June $9 \dagger$. & 26.7 & 21.5 & 18.2 & 18.2 & 21.9 & 23.0 & 27.8 & 23.5 & 20.7 & 21.6 & 23.4 & 25.8 \\
\hline June $23 .$. & 18.7 & 18.0 & 15.9 & 17.7 & 22.1 & 23.3 & 20.2 & 21.3 & 19.6 & 20.2 & 23.0 & 25.4 \\
\hline July 7 . & 26.8 & 22.5 & 19.8 & 19.7 & 19.9 & 22.0 & 16.6 & 18.9 & 17.7 & 18.4 & 20.1 & 22.1 \\
\hline July $21 .$. & 21.5 & 20.5 & 18.2 & 17.5 & 19.4 & 21.8 & 15.1 & 18.3 & 16.7 & 15.2 & 17.1 & 20.4 \\
\hline August 4. & 22.8 & 22.0 & 19.7 & 18.4 & 20.2 & 22.0 & 13.9 & 17.3 & 16.3 & 14.8 & 15.8 & 19.2 \\
\hline August 18 . & 17.7 & 20.0 & 16.9 & 15.0 & 17.4 & 21.6 & - & 16.7 & 16.0 & 15.0 & 15.9 & 18.0 \\
\hline September 22 . & 15.1 & 15.2 & 14.6 & 14.3 & 16.8 & 19.7 & 12.5 & 16.0 & 17.0 & 13.8 & 15.8 & 17.6 \\
\hline \multicolumn{13}{|l|}{ 1937: } \\
\hline May 18. & 14.1 & 18.1 & 19.1 & 20.4 & 21.6 & 22.9 & 16.2 & 22.4 & 21.1 & 20.5 & 20.9 & 25.6 \\
\hline June 1.. & 14.4 & 16.9 & 17.1 & 18.7 & 20.9 & 22.5 & 15.5 & 20.8 & 18.4 & 20.6 & 20.5 & 23.3 \\
\hline June 14 . & 24.7 & 21.6 & 18.6 & 17.6 & 20.0 & 22.9 & 13.8 & 19.5 & 19.4 & 19.2 & 20.6 & 22.1 \\
\hline June $29 \dagger$. & 22.7 & 21.7 & 20.1 & 19.3 & 20.2 & 24.5 & 17.8 & 200 & 19.2 & 17.2 & 19.5 & 22.7 \\
\hline July $13 \ldots$ & 16.8 & 19.0 & 17.6 & 15.4 & 17.7 & 22.8 & 15.5 & 18.9 & 17.9 & 16.1 & 18.5 & 21.7 \\
\hline July 27 . & 20.9 & 21.6 & 19.2 & 17.0 & 18.5 & 21.1 & 12.9 & 18.4 & 17.8 & 15.2 & 16.9 & 19.7 \\
\hline August 10. & 20.9 & 22.1 & 19.9 & 19.3 & 17.8 & 22.6 & 13.2 & 17.1 & 16.8 & 15.3 & 167 & 18.2 \\
\hline August 25 . & 17.7 & 19.6 & 16.7 & 15.7 & 16.3 & 19.1 & 12.8 & 16.2 & 15.7 & 14.1 & 15.0 & 17.7 \\
\hline
\end{tabular}

* Irrigated July 3 and July 27, 1936; and June 8 and July 14, 1937.

† Rain before sampling.

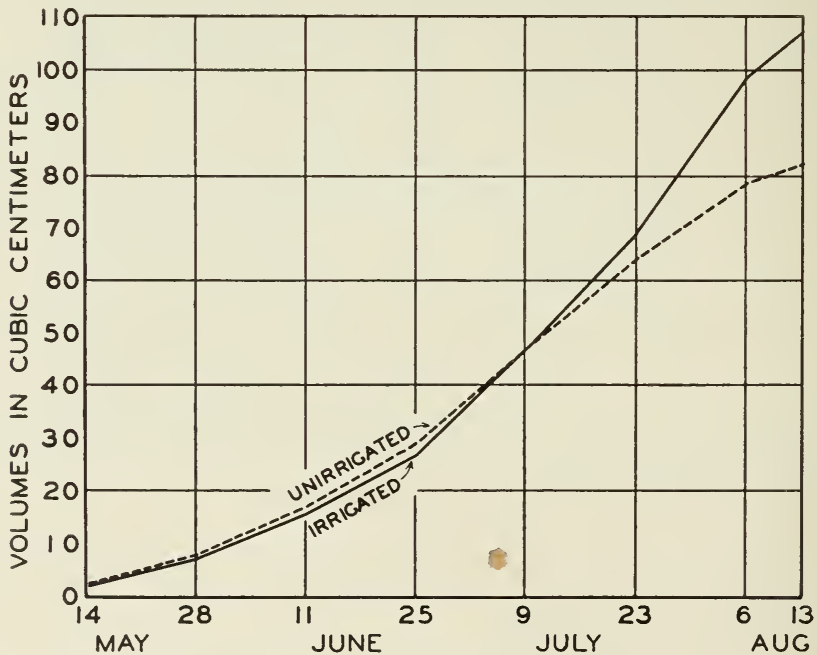

Fig. 4.-Sizes of pears in the Benson orchard, 1935. 
June 8 and July 14 in 1937. In addition, both plots were irrigated May 9,1936 , in order to disk the covercrop. The irrigation dates varied from year to year because of the necessity of avoiding conflicts with the spray program. The depths of penetration for the different irrigations are indicated by the increased moisture contents of the top 3 or 4 feet of soil on the sampling dates immediately after the irrigations. A rain of 2.2 inches occurred between June 1 and 8 in 1936, and one of 1.2 inches occurred on June 15, 1937. According to the data, the rate of extraction of moisture by the trees in the dry plot began to decrease materially between July 21 and August 4 in 1936 and between July 27 and August $10 \mathrm{in} \mathrm{1937.} \mathrm{In} \mathrm{other} \mathrm{words,} \mathrm{the} \mathrm{permanent} \mathrm{wilting} \mathrm{percentage} \mathrm{was} \mathrm{reached}$ later in the season, both in 1936 and 1937, than in 1935.

The sizes of pears from both plots for 1936 and 1937 are given in table 5 . These data when plotted give curves substantially similar to the one for 1935, which is given in figure 4. In all eases in the Benson orchard, the fruit from both plots increased at about the same rate so long as readily available moisture was present, but the fruit in the dry plot grew more slowly than that in the wet plot when the readily available moisture in the top 4 feet of soil in the former was about exhausted.

At harvest two pickings of two boxes from each plot were taken to Davis for storage tests. Each picking was divided into two lots, one being stored at $32^{\circ} \mathrm{F}$, the other at $50^{\circ}$. The fruit was tested with the standard pressure tester on arrival and at frequent intervals thereafter. The dates of picking and the pressure tests of the pears upon reaching Davis were as follows :

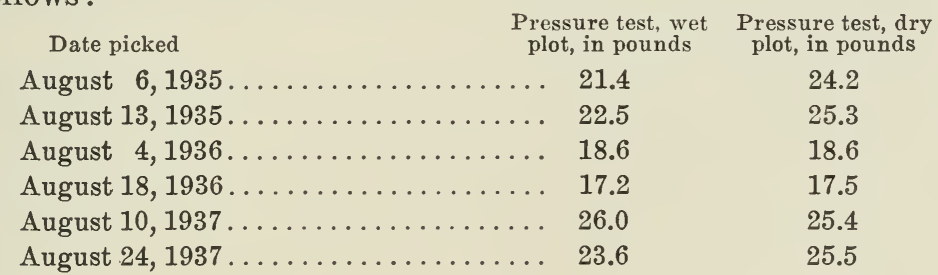

The pressure tests showed different results in 1935 than in 1936 and 1937. In 1935, when the fruit was picked 3 or 5 weeks after the soil in the dry plot was reduced to the permanent wilting percentage, the fruit from the dry plot was harder than that from the wet one. No significant differences were found in 1936 in either picking in the pressure tests, although the fruit started to slow down in growth July 21. In 1937 the fruit from the wet plot was slightly but not significantly harder than that from the dry at the first picking, but 2 weeks later the fruit from the dry plot was significantly harder than that from the wet. Apparently, if the soil moisture is reduced to the permanent wilting percentage long 
enough before picking, the unfavorable soil-moisture conditions are reflected in an increase in the pressure tests.

In the storage tests, if the fruit from the dry plot was harder than that from the wet, it tended to remain so while kept at $36^{\circ} \mathrm{F}$. After removal to room temperature, however, the pressure differences disappeared, and fruit from both plots reached prime eating condition at about the same time. The stored fruit ripened more rapidly at $50^{\circ}$ than at $36^{\circ}$, and the differences in pressure tests diminished. Color changes pro-

\section{TABLE 5}

Average Volumes of Pears, Benson Orchard, Kelseyville, 1936 and 1937

\begin{tabular}{|c|c|c|c|c|c|}
\hline \multicolumn{3}{|c|}{1936} & \multicolumn{3}{|c|}{1937} \\
\hline Date & Wet & Dry & Date & Wet & Dry \\
\hline & $\begin{array}{l}c c \\
3.6\end{array}$ & $\begin{array}{l}c c \\
4.4\end{array}$ & & $\begin{array}{l}c c \\
29\end{array}$ & $\begin{array}{l}c c \\
3.3\end{array}$ \\
\hline $\begin{array}{l}\text { May } 12 \ldots \ldots \ldots \\
\text { May } 26 \ldots \ldots \ldots\end{array}$ & $\begin{array}{l}3.0 \\
9.9\end{array}$ & $\begin{array}{r}4.4 \\
11.0\end{array}$ & Juay 1 . 1 ............ & $\begin{array}{l}2.9 \\
9.0\end{array}$ & $\begin{array}{l}3.3 \\
9.6\end{array}$ \\
\hline June 9... & 17.8 & 19.5 & June $14 \ldots \ldots \ldots$ & 17.8 & 19.9 \\
\hline June $23 \ldots$ & 32.0 & 34.5 & June $29 \ldots \ldots$ & 20.6 & 33.5 \\
\hline July $7 \ldots$. & 52.3 & 53.0 & July 13. & 42.2 & 47.1 \\
\hline July $21 \ldots \ldots$ & 78.0 & 71.9 & July $27 \ldots \ldots$ & 61.6 & 61.6 \\
\hline July $29 \ldots$. & 94.0 & 81.6 & August $10 \ldots$. & 80.7 & 70.3 \\
\hline August 4. & 106.5 & 88.1 & August $24 \ldots$. & 92.0 & 73.7 \\
\hline August 18. & 136.0 & 102.2 & & & \\
\hline
\end{tabular}

gressed at about the same rate in the fruit from both treatments. At maturity the only distinguishing characteristic was the somewhat smaller size of the fruit from the dry plot.

Cleland Orchard.-The Bartlett pear trees in the Cleland orchard were on Japanese-pear rootstock, about twenty years old, and planted 20 feet apart. The orchard was situated in Potter Valley, Mendocino County, on the bank of the east fork of the Russian River. Except during flood periods, the level of this stream was about 20 feet below the ground level of the experimental plots. The soil was classified as a Yolo fine sandy loam, stream-bottom phase. About 2 feet beneath the surface, a layer of fine-textured soil made sampling difficult at times, but did not seem to interfere with drainage. The climatic conditions resembled those in the Benson orchard at Kelseyville; but the annual rainfall was considerably more, averaging 30-35 inches.

Two plots of six trees each were used, and the same general procedure was followed as with the other plots under experimentation. Table 6 gives the water-holding properties of the soil, figure 5 the soil-moisture record for 1938. After the heavy rains during the winter of 1937-38, the soil in both plots was filled to field capacity to a depth of at least 12 
feet. Beginning with the initial sampling on April 23, the soil moisture was approximately equal in both plots until shortly after June 22 , when the wet plot was irrigated. A second application of water was given the wet plot on July 20. Both irrigations penetrated to a depth of 6 feet; and, apparently, some water was added to the supply in the 6-to-9-foot depth. The moisture contents of the soil in both plots were reduced to about the permanent wilting percentage on June 22 in the top 4 feet.

TABLE 6

Moisture Equivalents and Permanent Wilting Percentages of Yolo Fine Sandy Loam Soil from the Cleland ORCHARD, PotTer VAlley

\begin{tabular}{|c|c|c|c|}
\hline Depth & $\begin{array}{l}\text { Moisture } \\
\text { equivalent } \\
\text { (M.E.) }\end{array}$ & $\begin{array}{l}\text { Permanent } \\
\text { wilting } \\
\text { percentage } \\
\text { (P.W.P.) }\end{array}$ & $\frac{\text { M.E. }}{\text { P.W.P. }}$ \\
\hline $\begin{array}{l}\text { feet } \\
0 \text { to } 1 \ldots \ldots \ldots \\
1 \text { to } 2 \ldots \ldots \ldots \\
2 \text { to } 3 \ldots \ldots \ldots \\
3 \text { to } 4 \ldots \ldots \ldots \ldots \\
4 \text { to } 5 \ldots \ldots \ldots \ldots \\
5 \text { to } 6 \ldots \ldots \ldots \ldots \\
6 \text { to } 9 \ldots \ldots \ldots \ldots \\
9 \text { to } 12 \ldots \ldots \ldots \ldots\end{array}$ & $\begin{array}{c}\text { per cent } \\
16.0 \\
15.8 \\
19.8 \\
22.9 \\
21.5 \\
20.4 \\
17.7 \\
16.9\end{array}$ & $\begin{array}{c}\text { per cent } \\
6.7 \\
8.5 \\
10.9 \\
12.0 \\
11.5 \\
11.1 \\
7.6 \\
7.7\end{array}$ & $\begin{array}{l}\text { ratio } \\
2.39 \\
1.86 \\
1.82 \\
1.91 \\
1.87 \\
1.84 \\
2.33 \\
2.19\end{array}$ \\
\hline
\end{tabular}

In the wet plot this condition prevailed only until June 27, when water was applied; but in the dry it lasted through the remainder of the growing season. Furthermore, the available moisture in the dry plot was exhausted in the fifth foot on July 6, in the sixth on August 3. The trees in the dry plot could not secure enough water from the available supply below 6 feet to maintain a normal growth of fruit, as is shown later (fig. 6). Apparently more water was extracted from the 6-to-9-foot depth in the dry plot than in the wet, whereas in the 9-to-12-foot depth the extraction was about equal in both plots.

According to the soil-moisture curves, under conditions prevailing in the Cleland orchard, with the soil at field capacity at the beginning of the season, the trees use the water fast enough to necessitate a first irrigation between the middle and the last of June. At that time the soil moisture resulting from the winter rains is exhausted to a depth of 4 or 5 feet, and the supply should be replenished in order for the tree to function normally.

Figure 6 gives the average volumes of 100 pears in each plot in 1938 . The fruit in both plots grew at about the same rate from May 10 to June 22 , when the pears in the dry plot began to grow more slowly than those in 


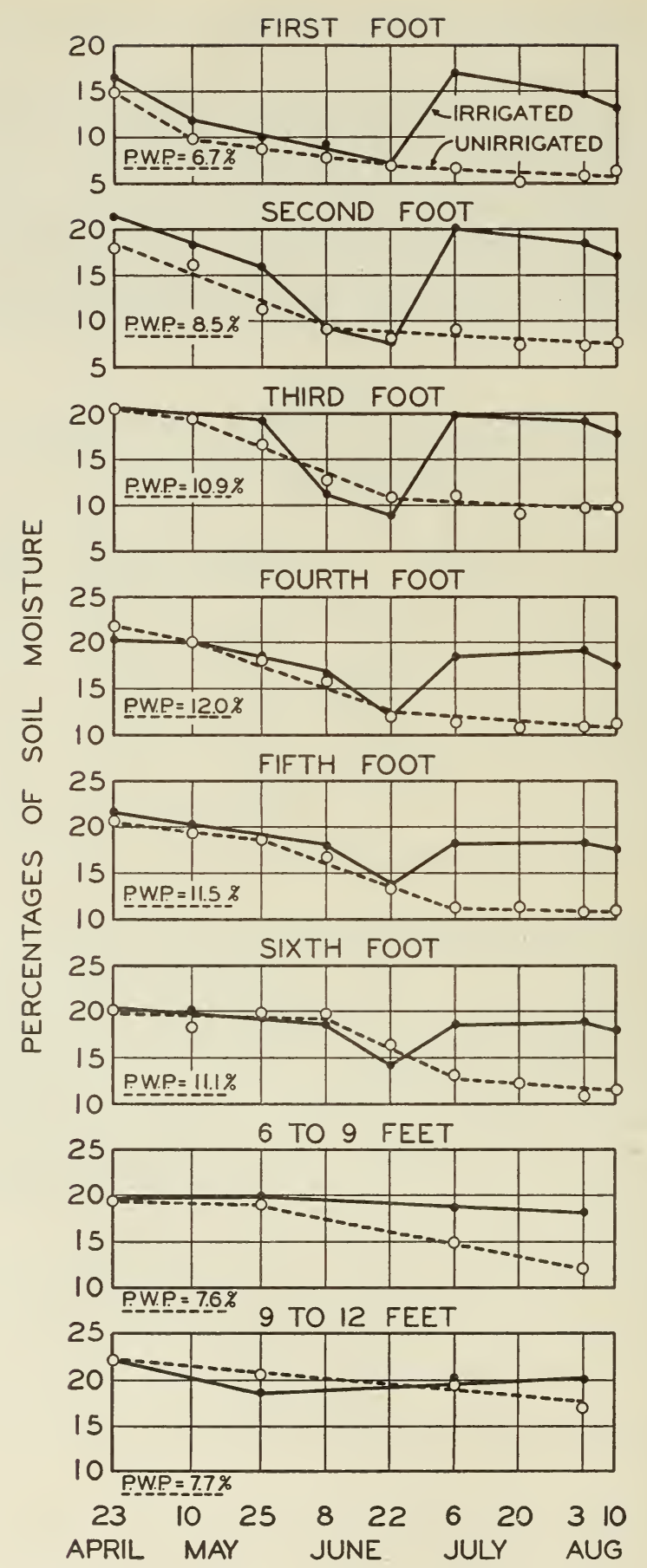

Fig. 5.-Soil-moisture conditions in the Cleland orchard, Potter Valley, 1938. The permanent wilting percentage is indicated by the letters P.W.P. The wet plot was irrigated June 22 and July 20. 
the wet. The differences in size increased until August 9, when the crop was harvested. Just as in the Benson orchard, the slow growth of fruit in the dry plot started about the time when the readily available moisture was exhausted in that plot.

The soil-moisture results in 1936, 1937, and 1939 (table 7) resembled those in 1938. In each of these years the soil moisture was approximately at field capacity when the first samples were taken, about the middle of May, except in the top foot, where some moisture had been lost by evapo-

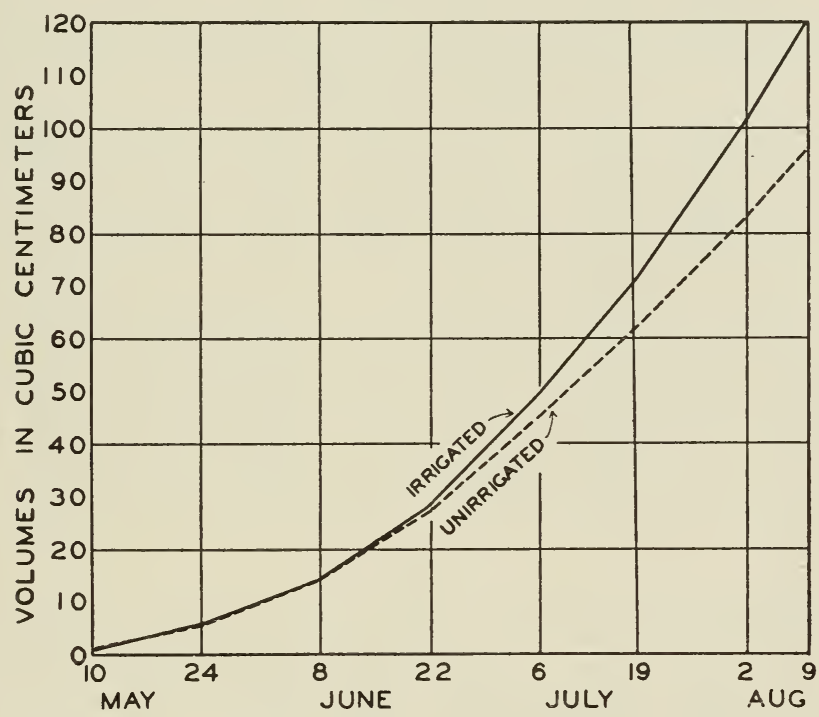

Fig. 6.-Sizes of pears in the Cleland orchard, 1938.

ration from the surface and by transpiration from the covercrop. The moisture supply in both plots was increased by a rain of 2.7 inches during the first week in June in 1936. The wet plot was irrigated July 8 in 1936 and again 10 days later, the soil being wet to a depth of more than 6 feet. In the wet plot the soil moisture was above the wilting percentage while the fruit was on the trees, but the wilting percentage was reached in the dry plot in the top 4 feet about July 22 in 1936.

In 1937 the dry plot was accidentally irrigated on June 8, while the wet plot was being watered, and, with a rain of slightly more than an inch on June 15, was wetted to a depth of about 6 feet. The wet plot was irrigated a second time on July 23. The readily available moisture in the dry plot was almost exhausted in the top 4 feet on July 28, or about a week before the first picking of 1937. The accidental irrigation on June 8 supplied this plot with sufficient moisture to maintain the available supply about a week longer than in 1936. As was the case in 1938, some 
TABLE 7

Average Soil-Moisture Percentages, Cleland Orchard, Potter Valley, 1936, 1937, AND 1939

\begin{tabular}{l|l|l|l|l|l|l|l|l|}
\hline Date & $0-1 \mathrm{ft}$. & $1-2 \mathrm{ft}$. & $2-3 \mathrm{ft}$. & $3-4 \mathrm{ft}$. & $4-5 \mathrm{ft}$. & $5-6 \mathrm{ft}$. & $6-9 \mathrm{ft}$. & $9-12 \mathrm{ft}$. \\
\hline
\end{tabular}

Wet plot*

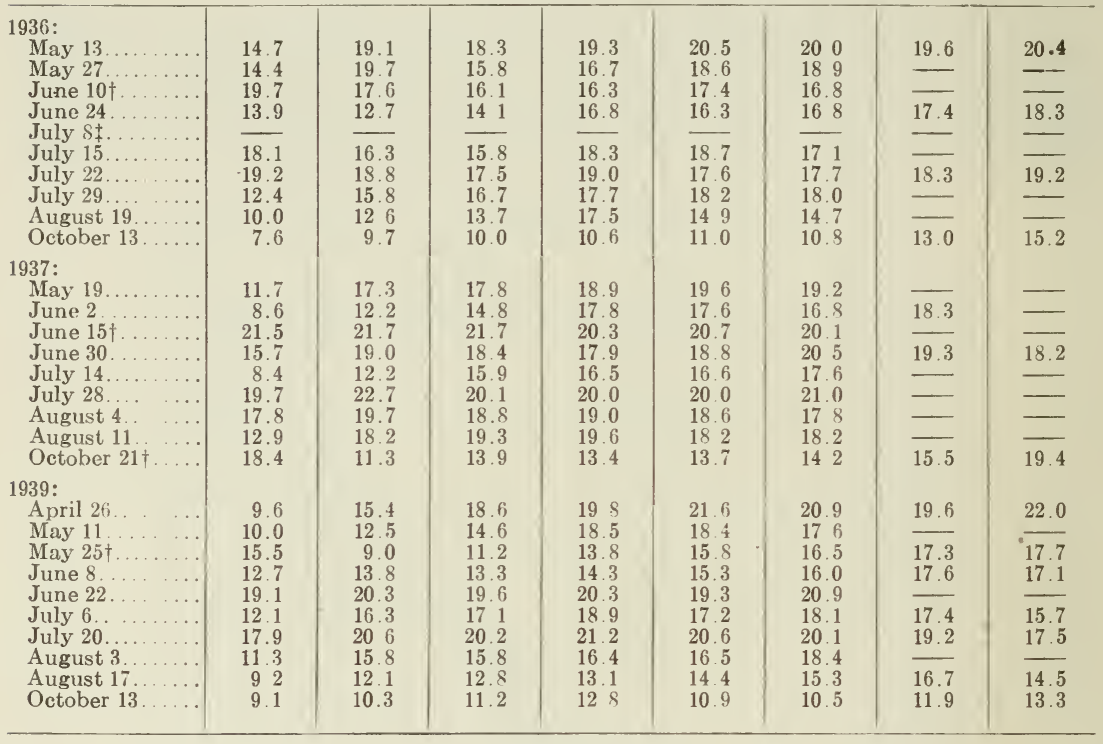

Dry plot

\begin{tabular}{|c|c|c|c|c|c|c|c|c|}
\hline 1936: & & & & & & & & \\
\hline May 13. & 12.4 & 16.7 & 16.7 & 20.3 & 19.5 & 20.1 & 19.4 & 21.7 \\
\hline May 27. & 13.4 & 15.2 & 16.5 & 16.7 & 18.2 & 19.3 & & \\
\hline June $10 \dagger \ldots$ & 20.2 & 17.2 & 15.1 & 16.2 & 17.2 & 18.1 & & \\
\hline June $24 \ldots \ldots$ & 12.1 & 14.8 & 14.7 & 14.9 & 15.4 & 161 & 17.9 & 19.3 \\
\hline July $\& \ldots . . .$. & 9.1 & 10.5 & 12.3 & 13.8 & 12.7 & 14.9 & & - \\
\hline July $15 \ldots \ldots$ & 8.2 & 9.4 & 12.0 & 13.3 & 13.8 & 15.3 & & - \\
\hline July $22 \ldots$ & 7.7 & 9.5 & 11.0 & 12.5 & 13.0 & 132 & 13.4 & 17.3 \\
\hline July 29. & 7.4 & 8.5 & 10.9 & 12.2 & 11.7 & 12.5 & & \\
\hline August $19 \ldots \ldots$. & 6.0 & 9.0 & 11.8 & 12.4 & 12.4 & 11.8 & & \\
\hline October $13 \ldots$. & 6.1 & 8.5 & 10.4 & 11.0 & 10.7 & 11.1 & 11.5 & 15.5 \\
\hline 1937: & & & & & & & & \\
\hline May 19 & 9.8 & 15.1 & 19.7 & 20.2 & 20.1 & 20.1 & & \\
\hline June 2 . & 7.6 & 11.0 & 16.2 & 17.9 & 18.5 & 18.6 & 19.3 & 19.6 \\
\hline June $15+\$ \ldots . .$. & 18.7 & 22.6 & 21.3 & 20.3 & 19.3 & 19.7 & & \\
\hline June $30 \ldots \ldots \ldots$ & 13.2 & 17.8 & 20.9 & 18.9 & 18.9 & 19.2 & 19.3 & 19.9 \\
\hline July $14 \ldots \ldots \ldots$ & 10.3 & 14.2 & 15.2 & 17.0 & 16.3 & 17.7 & & \\
\hline July $28 \ldots \ldots \ldots$ & 8.5 & 9.8 & 12.2 & 13.8 & 14.7 & 17.3 & $\longrightarrow$ & 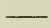 \\
\hline August $4 \ldots \ldots \ldots$ & 71 & 9.0 & 11.7 & 13.2 & 13.4 & 15.8 & $\underline{-}$ & $\longrightarrow$ \\
\hline August $11 \ldots \ldots$ & 7.3 & 9.4 & 12.1 & 13.2 & 12.9 & 14.2 & - & - \\
\hline October $21 \dagger \ldots$. & 14.1 & 9.2 & 10.7 & 12.7 & 12.2 & 12.1 & 14.8 & 19.4 \\
\hline 1939: & & & & & & & & \\
\hline April 26 & 8.8 & 13.8 & 19.1 & 20.5 & 19.3 & 19.1 & 18.9 & 19.6 \\
\hline May $11 \ldots \ldots \ldots$ & 7.2 & 10.4 & 14.4 & 17.3 & 18.2 & 17.3 & & \\
\hline May $25 \dagger \ldots \ldots \ldots$ & 14.7 & 7.8 & 11.3 & 14.2 & 15.6 & 17.3 & 18.3 & 19.8 \\
\hline June $8 \ldots \ldots \ldots$ & 11.2 & 10.4 & 13.5 & 15.7 & 16.2 & 17.1 & 17.6 & 18.8 \\
\hline June $22 \ldots \ldots$ & 8.7 & 9.7 & 11.7 & 13.0 & 15.0 & 15.9 & & \\
\hline July $6 \ldots \ldots$ & 7.8 & 8.9 & 11.2 & 12.9 & 12.6 & 14.0 & 15.7 & 17.2 \\
\hline July $20 \ldots \ldots \ldots$ & 7.1 & 9.1 & 12.7 & 12.7 & 13.0 & 14.1 & 15.1 & 18.7 \\
\hline August $3 \ldots$ & 5.9 & 8.2 & 10.1 & 11.7 & 12.3 & 12.8 & $\frac{\infty}{20}$ & \\
\hline August $17 \ldots \ldots$ & 5.8 & 7.8 & 10.5 & 11.1 & 10.1 & 11.0 & 12.8 & 14.3 \\
\hline October $13 \ldots .$. & 6.6 & 7.9 & 9.7 & 10.6 & 10.1 & 9.9 & 10.3 & 11.9 \\
\hline
\end{tabular}

* Irrigated July 8 and July 18 in 1936; June 8 and July 23 in 1937; and June 17 and July 18 in 1939.

† Rain before sampling.

$¥$ Wet plot being irrigated, could not be sampled.

$\S$ Accidental irrigation before sampling. 
water was removed from the 6-to-9-foot depth, but very little from the 9-to-12-foot depth; but the amount thus secured did not keep the fruit in the dry plot growing so fast as that in the wet one. In 1939 both plots had about the same moisture conditions from late in April until June 17 when the wet plot was irrigated. A second irrigation applied to the wet plot on July 18 kept the soil moisture in the top 6 feet above the permanent wilting percentage until after the crop was picked. The soil mois-

TABLE 8

Average Volumes of Pears, Cleland Orchard, Potter Valley, 1936,1937 , and 1939

\begin{tabular}{|c|c|c|c|c|c|c|c|c|}
\hline \multicolumn{3}{|c|}{1936} & \multicolumn{3}{|c|}{1937} & \multicolumn{3}{|c|}{1939} \\
\hline Date & Wet & Dry & Date & Wet & Dry & Date & Wet & Dry \\
\hline May $13 .$. & $\begin{array}{l}c c \\
5.0\end{array}$ & $\begin{array}{l}c c \\
5.4\end{array}$ & May 19. & $\begin{array}{l}c c \\
3.5\end{array}$ & $\begin{array}{l}c c \\
3.5\end{array}$ & May $11 \ldots$ & $\begin{array}{l}c c \\
5.6\end{array}$ & $\begin{array}{l}c c \\
5.9\end{array}$ \\
\hline May $27 .$. & 11.3 & 12.0 & June $1 . .$. & 10.3 & 10.1 & May $25 .$. & 12.5 & 12.8 \\
\hline June $10 \ldots$ & 20.2 & 21.3 & June $14 \ldots .$. & 21.7 & 22.1 & June $8 \ldots$. . . & 24.4 & 24.8 \\
\hline June $24 \ldots$. & 36.1 & 37.7 & June $29 \ldots$ & 40.5 & 39.9 & June $22 \ldots$ & 42.2 & 41.1 \\
\hline July $8 \ldots .$. & - & 56.5 & July $13 \ldots$ & 63.1 & 62.4 & July $6 \ldots \ldots$ & 67.8 & 63.9 \\
\hline July $15 \ldots$ & 73.6 & 71.9 & July $27 \ldots$. & 960 & 87.2 & July $20 \ldots .$. & 99.1 & 85.2 \\
\hline July $22 \ldots$ & 872 & 82.5 & August $4 \ldots$ & 115.4 & 100.0 & August $3 \ldots$ & 129.7 & 101.1 \\
\hline July $29 \ldots$. & 99.1 & 91.0 & August 10. & 1322 & 109.7 & & & $\ldots$ \\
\hline
\end{tabular}

ture in the dry plot was reduced to about the permanent wilting percentage in the top 4 feet on July 6 .

Table 8 gives the fruit sizes for 1936, 1937, and 1939. When plotted, these data show that growth of the fruit in the dry plot slackened each year near the time when the readily available moisture was exhausted in that plot. The dates of picking and the pressure tests of the pears from the Cleland orchard were as follows :

\begin{tabular}{|c|c|c|}
\hline Date picked & $\begin{array}{l}\text { Pressure test, wet } \\
\text { plot, in pounds }\end{array}$ & $\begin{array}{l}\text { Pressure test, dry } \\
\text { plot, in pounds }\end{array}$ \\
\hline July 29, 1936 . & 17.2 & 17.2 \\
\hline August $19,1936$. & 16.0 & 16.9 \\
\hline August 4,1937 . & 23.7 & 26.1 \\
\hline August 11, 1937 . & . . 20.8 & 24.6 \\
\hline August 3,1938 . & 20.6 & 24.8 \\
\hline August 10,1938 . & $\begin{array}{ll}\ldots & 20.3\end{array}$ & 21.9 \\
\hline August 3,1939 . & . . 18.5 & 21.5 \\
\hline August 17, 1939 . & 20.3 & 19.5 \\
\hline
\end{tabular}

The fruit from the dry plot was harder than that from the wet in 1937, in 1938, and in the first picking of 1939, but in 1936 only a slight difference in the second picking was obtained. In 1936 the available soil moisture in the dry plot was not exhausted until July 22 , and picking started 


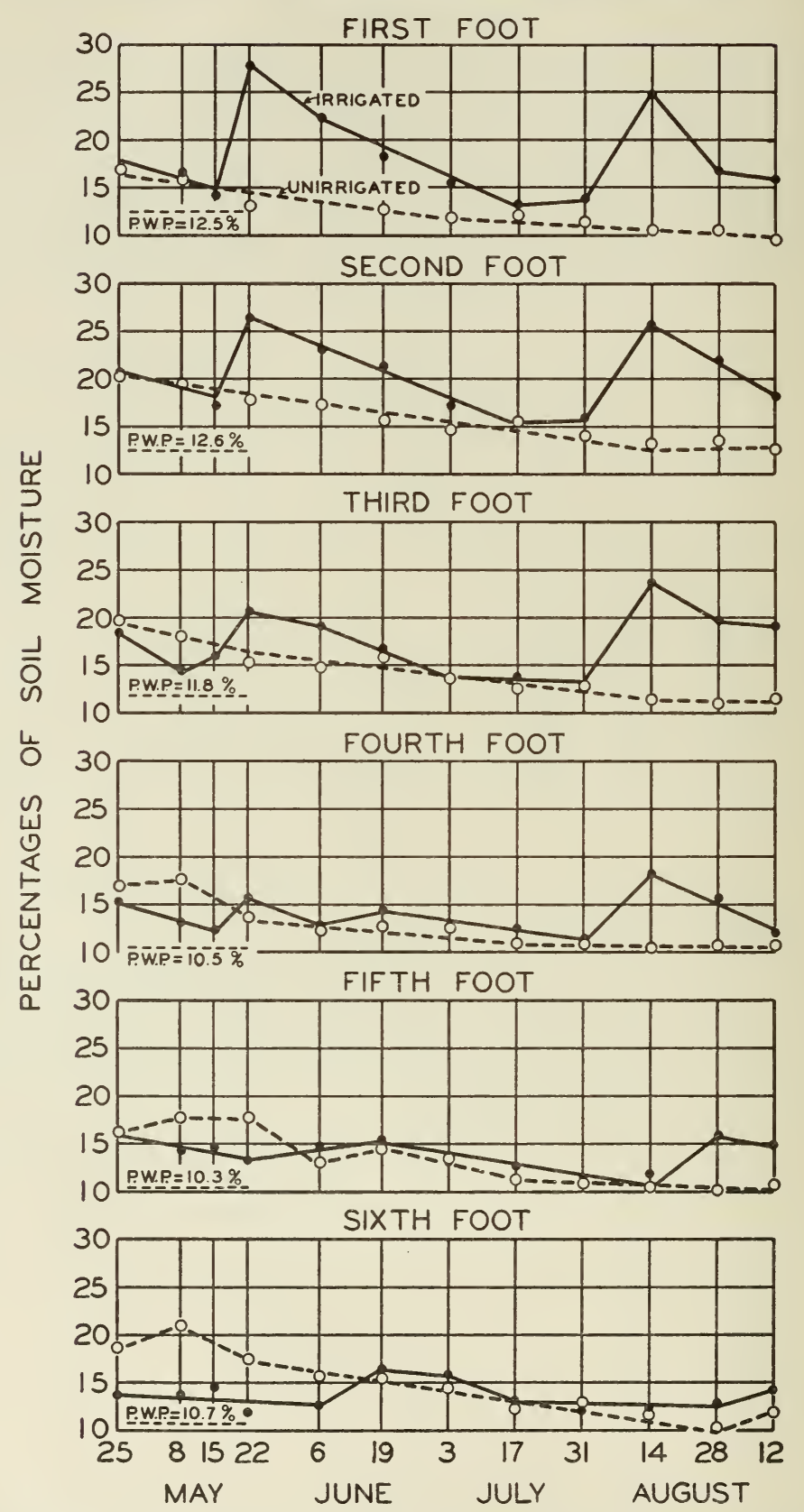

Fig. 7.-Soil-moisture conditions in the University Farm orchard, Davis, 1934. The permanent wilting percentage is indicated by the letters P.W.P. The wet plots were irrigated May 18 and August 10. 
a week later. In 1937, on the other hand, although because of an accidental irrigation in June the available soil moisture in the dry plot was not exhausted until picking time or shortly before, markedly higher pressure tests were secured than in the wet plot. In 1938 the trees in the dry plot were without readily available soil moisture after June 22 , and the pears were considerably harder in this plot than in the irrigated one. In 1939 the available soil moisture was exhausted shortly after June 22 in the dry

\section{TABLE 9}

Moisture Equivalents and Permanent Wilting Percentages OF Yolo LOAM SOIL From THE UNIVERSITY

FARM ORChard, Davis

\begin{tabular}{|c|c|c|c|}
\hline Depth & $\begin{array}{l}\text { Moisture } \\
\text { equivalent } \\
\text { (M.E.) }\end{array}$ & $\begin{array}{l}\text { Permanent } \\
\text { wilting } \\
\text { percentage } \\
\text { (P.W.P.) }\end{array}$ & $\frac{\text { M.E. }}{\text { P.W.P. }}$ \\
\hline 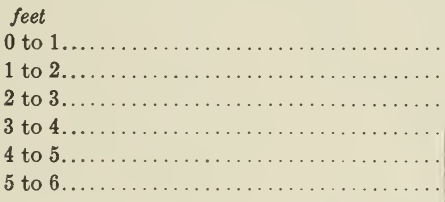 & $\begin{array}{c}\text { per cent } \\
24.2 \\
24.3 \\
22.7 \\
19.6 \\
21.6 \\
21.6\end{array}$ & $\begin{array}{c}\text { per cent } \\
12.5 \\
12.6 \\
11.8 \\
10.5 \\
10.3 \\
10.7\end{array}$ & $\begin{array}{l}\text { ratio } \\
1.94 \\
1.93 \\
1.92 \\
1.87 \\
2.10 \\
2.02\end{array}$ \\
\hline
\end{tabular}

plot, and the pears from the first picking in this plot on August 3 were harder than those from the wet plot.

The differences in firmness tended to disappear in storage. The pressure tests of the fruit from the dry plot in the $50^{\circ} \mathrm{F}$ storage tended to approach those of the fruit from the wet plot more rapidly than in the $36^{\circ}$ storage. After removal from storage, fruit from both plots ripened rather quickly, and when fully ripe had apparently the same quality.

University Farm Orchard.-Two plots each of the Bartlett and Winter Nelis varieties on Japanese-pear rootstock, planted 27 feet apart, were used in 1934, 1935, and 1936. The plots contained 10 trees each. The trees, though planted in 1923, were small for their age because of heavy pruning during several epidemics of pear blight. The soil was classified as a Yolo loam with excellent drainage. Climatic conditions were typical of the interior valleys. The plots were cultivated several times during the season, and no covercrop was planted. Table 9 gives the water-holding properties.

The curves in figure 7 indicate the average soil-moisture conditions in the Bartlett and Winter Nelis plots in 1934. The wet plots were irrigated on May 18 and on August 10. Rain, early in June, added some moisture to the top foot in both plots. Since the samples were taken as soon as 
possible after irrigation, and before the water had reached the greatest limit of penetration, the increase in moisture content in the fifth foot occurred about a week later than it did in the upper 4 feet, and in the sixth foot, still later. As usual, the dry plots were not irrigated during the growing season. The permanent wilting percentage was reached about July 3 in the top foot, about August 1 in the second, August 15 in

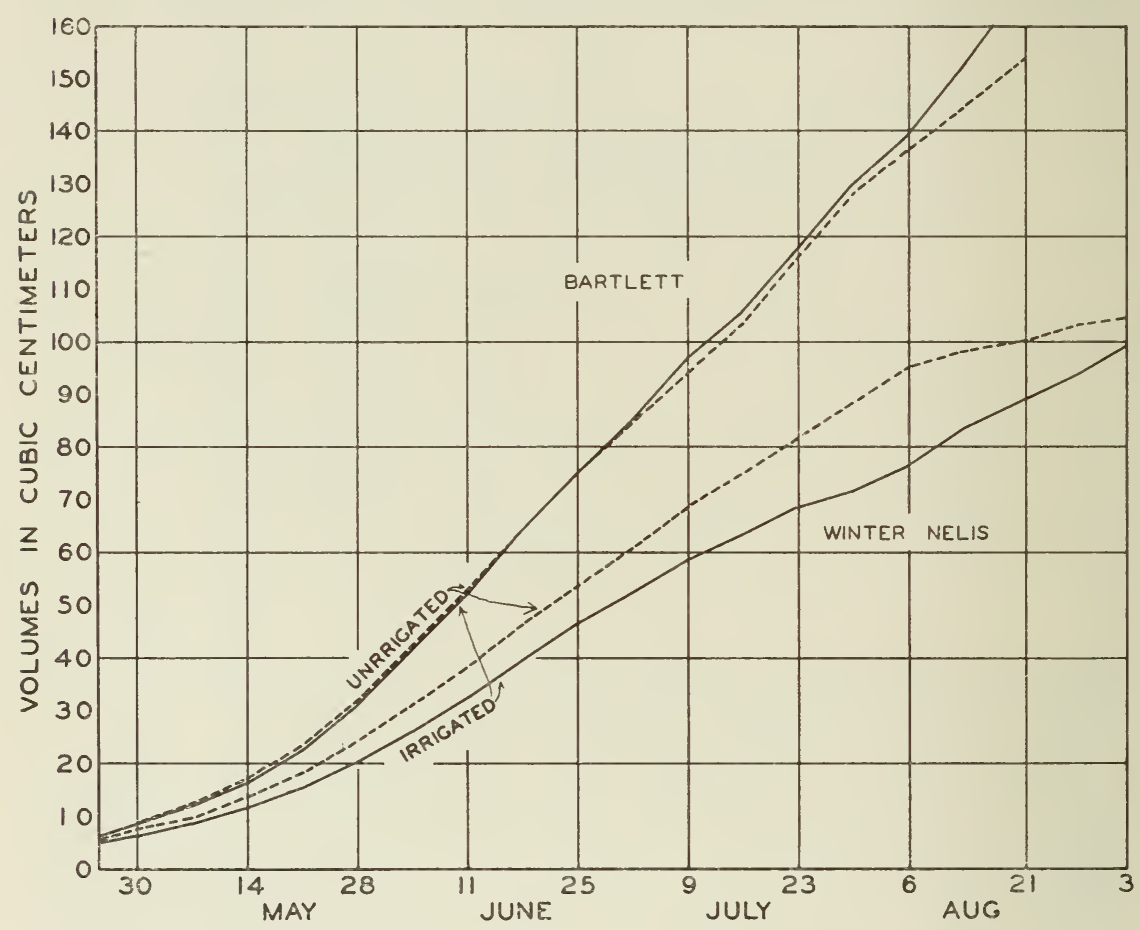

Fig. 8.-Sizes of pears in the University Farm orchard, 1934.

the third, July 17 in the fourth, and August 15 in the fifth foot in both the Bartlett and Winter Nelis plots; pockets of fine gravel in the sixth foot made the results erratic at this depth. Thus the permanent wilting percentage was not reached in the top 5 feet until comparatively late in the season in 1934, possibly because of cool weather and some showers during June.

Figure 8 shows the growth of the Bartlett and Winter Nelis pears in 1934. The growth of the Bartlett pears in both plots was substantially the same until after August 6, after which the fruit grew more slowly in the dry plot than in the wet. The fruits of the Winter Nelis pears in the dry plot increased more rapidly in size than those in the wet during the early part of the season, but slowed down appreciably after August 6 . 
As the soil-moisture record shows, the permanent wilting percentage was reached in the top 5 feet about the time the fruit in the dry plot began to slow down in growth.

TABLE 10

Average Soll-Moisture Percentages, University Farm Orchard, Davis, 1935 AND 1936

\begin{tabular}{|c|c|c|c|c|c|c|c|c|c|c|c|c|}
\hline \multirow{2}{*}{ Date } & \multicolumn{6}{|c|}{ Wet plot* } & \multicolumn{6}{|c|}{ Dry plot } \\
\hline & $\begin{array}{l}0-1 \\
\mathrm{ft} .\end{array}$ & $\begin{array}{l}1-2 \\
\mathrm{ft} .\end{array}$ & $\begin{array}{l}2-3 \\
\mathrm{ft} .\end{array}$ & $\begin{array}{c}3-4 \\
\mathrm{ft} .\end{array}$ & $\begin{array}{l}4-5 \\
\mathrm{ft} .\end{array}$ & $\begin{array}{l}5-6 \\
\mathrm{ft} .\end{array}$ & $\begin{array}{l}0-1 \\
\mathrm{ft} .\end{array}$ & $\begin{array}{l}1-2 \\
\mathrm{ft} .\end{array}$ & $\begin{array}{l}2-3 \\
\mathrm{ft} .\end{array}$ & $\begin{array}{l}3-4 \\
\mathrm{ft} .\end{array}$ & $\begin{array}{l}4-5 \\
\mathrm{ft} .\end{array}$ & $\begin{array}{l}5-6 \\
\mathrm{ft} .\end{array}$ \\
\hline & per & & & & & & & & & & & per \\
\hline 1935: & cent & cent & cent & cent & cent & cent & cent & cent & cent & cent & cent & cent \\
\hline May 25 & 16.1 & 19.6 & 16.4 & 15.9 & 17.8 & 15.3 & 16.8 & 21.9 & 19.1 & 18.2 & 18.0 & 17.8 \\
\hline June 8. . & 23.3 & 24.2 & 21.5 & 21.9 & 25.0 & 25.7 & 15.1 & 20.3 & 19.0 & 17.3 & 17.9 & 20.4 \\
\hline June 22. & 17.5 & 22.3 & 19.5 & 16.9 & 20.0 & 20.2 & 13.7 & 16.8 & 14.2 & 14.2 & 13.5 & 16.8 \\
\hline June 29. & 15.6 & 20.5 & 16.8 & 15.5 & 18.7 & 19.8 & 13.0 & 15.7 & 13.3 & 12.8 & 14.3 & 16.1 \\
\hline July 5 . . & 14.0 & 17.7 & 15.5 & 13.6 & 17.2 & 19.3 & 12.4 & 13.9 & 12.8 & 14.4 & 12.7 & 16.9 \\
\hline July 13. & 13.4 & 15.6 & 13.4 & 13.5 & 16.8 & 18.3 & 11.9 & 14.6 & 13.0 & 12.9 & 12.5 & 14.7 \\
\hline July 20 . & 12.0 & 15.1 & 14.6 & 12.5 & 14.2 & 15.2 & 11.6 & 14.4 & 12.7 & 9.9 & 12.2 & 14.0 \\
\hline July 27. & - & $\longrightarrow$ & - & - & - & - & 10.8 & 13.6 & 11.5 & 11.3 & 11.3 & 12.3 \\
\hline August 2 . & 22.8 & 22.2 & 18.6 & 14.0 & 14.8 & 15.9 & 10.2 & 12.6 & 11.8 & 10.6 & 11.6 & 11.6 \\
\hline August 9. & 21.3 & 23.4 & 19.0 & 16.7 & 18.3 & 18.6 & 10.3 & 13.5 & 12.0 & 10.5 & 10.8 & 12.8 \\
\hline August 17 . & 19.1 & 220 & 18.2 & 15.7 & 16.8 & 15.6 & 11.0 & 13.1 & 11.6 & 10.2 & 10.5 & 11.5 \\
\hline August 31 & 13.1 & 15.6 & 13.0 & 13.9 & 15.9 & 16.5 & 9.8 & 12.8 & 10.3 & 10.1 & 10.1 & 11.4 \\
\hline September 28 . & 11.2 & 13.4 & 10.5 & 9.8 & 11.7 & 11.2 & 10.1 & 13.4 & 12.1 & 10.8 & 11.4 & 12.4 \\
\hline \multicolumn{13}{|l|}{ 1936: } \\
\hline May 25. & 18.2 & 19.1 & 16.5 & 14.6 & 16.7 & 18.6 & 16.7 & 19.8 & 19.0 & 156 & 18.6 & 20.7 \\
\hline June 1. & 16.1 & 19.1 & 15.3 & 14.7 & 15.9 & 17.1 & 16.0 & 18.9 & 20.2 & 17.7 & 18.0 & 19.0 \\
\hline June 8 . . & 16.3 & 18.3 & 16.9 & 14.7 & 16.6 & 17.1 & 17.5 & 19.1 & 17.1 & 16.2 & 17.9 & 18.8 \\
\hline June 14 . . & 15.7 & 18.7 & 14.4 & 13.4 & 15.0 & 16.4 & 15.4 & 17.2 & 17.9 & 15.6 & 17.1 & 17.7 \\
\hline June 22 & 13.9 & 16.3 & 13.6 & 12.0 & 13.1 & 15.2 & 15.3 & 18.8 & 16.5 & 14.5 & 15.4 & 16.1 \\
\hline June 29. . & 13.6 & 15.4 & 13.1 & 10.9 & 11.7 & 13.5 & 11.3 & 15.5 & 14.8 & 12.9 & 14.1 & 13.3 \\
\hline July $6 \ldots$ & 27.3 & 25.7 & 22.3 & 15.0 & 15.4 & 18.1 & 12.4 & 14.4 & 13.0 & 11.0 & 12.9 & 15.7 \\
\hline July $13 \ldots$ & 21.7 & 23.6 & 20.4 & 15.6 & 14.5 & 17.3 & 12.4 & 14.9 & 13.6 & 12.4 & 13.2 & 15.0 \\
\hline July $20 \ldots$ & 16.7 & 21.3 & 17.4 & 15.3 & 16.1 & 18.0 & 11.8 & 15.3 & 13.7 & 13.4 & 13.4 & 14.9 \\
\hline July $27 \ldots$ & 17.0 & 22.6 & 20.1 & 16.2 & 16.2 & 17.7 & 11.5 & 14.2 & 14.0 & 11.3 & 11.6 & 12.3 \\
\hline August $3 \ldots$ & 14.6 & 18.1 & 12.5 & 11.9 & 12.3 & 14.0 & 10.2 & 13.1 & 13.7 & 12.5 & 11.9 & 15.0 \\
\hline August $10 \ldots$ & 13.4 & 16.0 & 13.3 & 9.5 & 10.1 & 11.3 & 9.4 & 13.0 & 12.1 & 10.6 & 10.7 & 11.6 \\
\hline August 24 . & 25.4 & 26.3 & 23.1 & 18.5 & 17.2 & 17.0 & 11.6 & 15.3 & 12.4 & 10.8 & 11.7 & 13.4 \\
\hline September 7 & 19.5 & 23.7 & 20.3 & 14.1 & 15.6 & 16.2 & 10.4 & 13.4 & 9.6 & 11.0 & 11.0 & 11.5 \\
\hline
\end{tabular}

* Irrigated June 5 and July 28, 1935; and July 1 and August 14, 1936.

Table 10 gives the soil-moisture percentages for the plots at Davis for 1935 and 1936. The wet plots were irrigated on June 5 and July 28 in 1935; on July 1 and August 14 in 1936. In the dry plots in 1935 the data plotted show a marked change in the slope of the extraction curves about June 29 in the first foot; July 5 in the second and third; July 13 in the fourth foot; August 9 in the fifth; and August 17 in the sixth. The moisture content at which the change in slope of the extraction curves occurred coincided closely with the permanent wilting percentage. The results in 1936 were similar to those both in 1934 and 1935, and when plotted, the change in slope of the soil moisture curves occurred 
about June 29 in the first foot; July 6 in the second, third, fourth, and fifth foot. Apparently the permanent wilting percentage was not reached in the sixth foot.

Table 11 gives the average sizes for pears for 1935 and 1936. From this table it may be seen that while the Bartletts increased in size at substantially the same rate during the early part of the season in 1936 the Winter

TABLE 11

Average Volumes of Pears, University Farm Orchard, Davis, 1935 and 1936

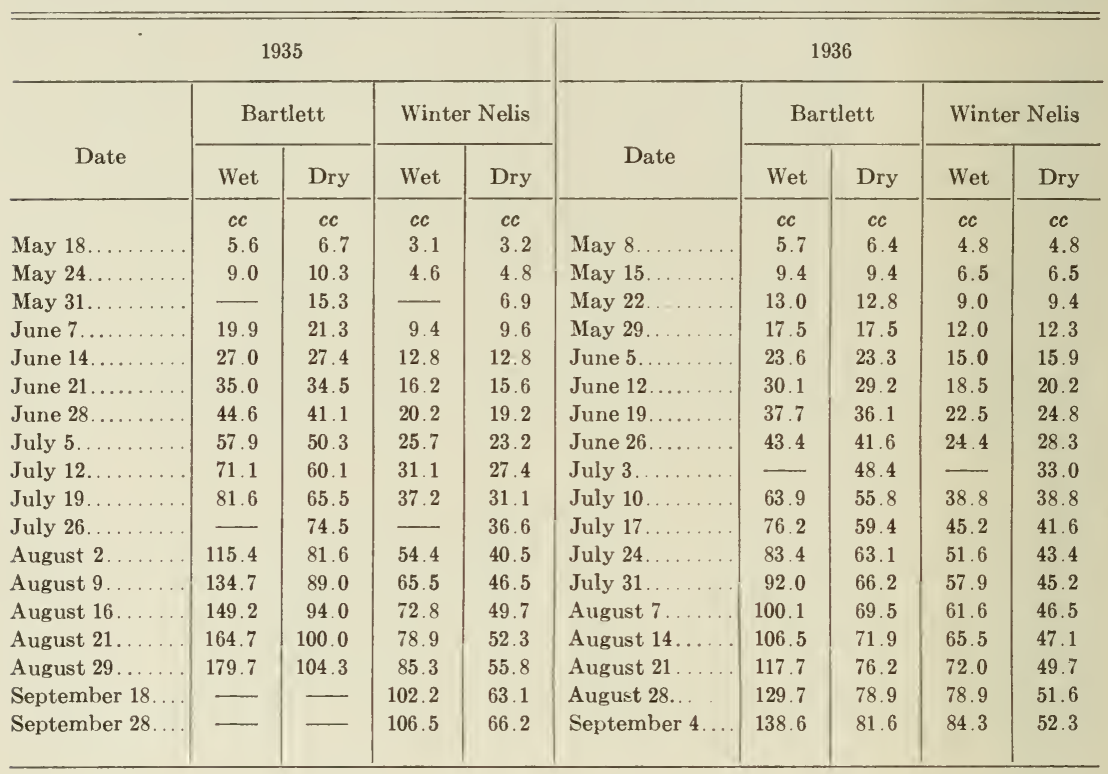

Nelis in the dry plot grew faster than those in the wet for several weeks in the early part of the season, as they did in 1934. A marked decrease in rate of growth of both varieties of pears in the dry plot occurred between June 28 and July 5 in 1935 and between June 26 and July 3 in 1936.

The pressure tests for the pears from Davis follow :

\begin{tabular}{|c|c|c|}
\hline $\begin{array}{l}\text { Variety and } \\
\text { date picked }\end{array}$ & $\begin{array}{l}\text { Pressure test, wet } \\
\text { plot, in pounds }\end{array}$ & $\begin{array}{l}\text { Pressure test, dry } \\
\text { plot, in pounds }\end{array}$ \\
\hline \multicolumn{3}{|l|}{ Bartlett: } \\
\hline July $18,1934 \ldots \ldots \ldots \ldots \ldots \ldots$ & . 19.8 & 23.1 \\
\hline July $31,1934 \ldots \ldots \ldots \ldots \ldots \ldots$ & . $\quad 22.6$ & 24.0 \\
\hline August $5,1935 \ldots \ldots \ldots \ldots \ldots \ldots$ & . 28.6 & 28.9 \\
\hline August $19,1935 \ldots \ldots \ldots \ldots \ldots$ & . . 27.1 & 28.6 \\
\hline July $25,1936 \ldots \ldots \ldots \ldots \ldots \ldots$ & . $\quad 17.8$ & 21.5 \\
\hline August $8,1936 \ldots \ldots \ldots \ldots \ldots \ldots$ & . 17.4 & 18.1 \\
\hline \multicolumn{3}{|l|}{ Winter Nelis: } \\
\hline September $12,1934 \ldots \ldots \ldots \ldots \ldots$ & . . 22.7 & 23.7 \\
\hline September $14,1936 \ldots \ldots \ldots \ldots \ldots$ & .. 16.7 & 19.3 \\
\hline
\end{tabular}


The pears from the dry plots were consistently harder than those from the wet. As with the fruit from the other orchards previously reported, the pressure differences in both varieties disappeared during storage and in the ripening period thereafter. The keeping qualities of the two lots were substantially the same.

Prost Orchard.-After a preliminary trial in 1938, two plots of eight Bartlett pear trees each were used in the Prost orchard near Concord, Contra Costa County, in 1939. The trees were about fifty years old, planted on French-pear rootstock 18 feet apart. The summer tempera-

TABLE 12

Moisture Equivalents and Permanent Wilting Percentages of Zamora Clay Loam Soll from the Prost Orchard, Concord

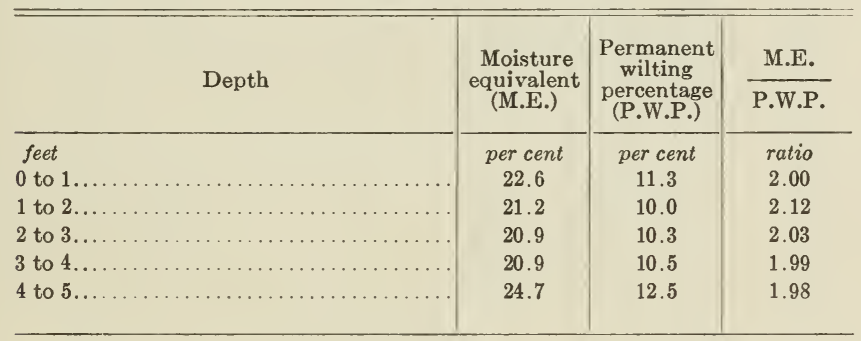

tures are somewhat higher than along the coast, and appreciably lower than in the interior valleys. The rainfall is variable, but is slightly less than along the coast. Table 12 shows the water-holding characteristics of the soil, a Zamora clay loam.

Because rainfall during the winter of 1938-39 was deficient, the wet plot was irrigated before the first samples were taken, consequently the wet plot started the season with more moisture present in the fourth and fifth foot than did the dry plot. Figure 9 gives the soil-moisture record for 1939. As is shown by the abrupt change in slope of the curve representing the moisture content of the dry plot on June 7, the permanent wilting percentage was reached comparatively early in the season. After June 7 the curves for the moisture contents of the dry plot remained approximately horizontal until shortly after July 19, when water was applied to ameliorate the moisture conditions in this plot. The wet plot was irrigated on June 1 and again on June 22.

Figure 10 shows the average volumes of 100 pears in each plot. The average increases in size were approximately equal in both plots between May 10 and May 24, after which the fruit grew more slowly in the dry plot than in the wet. As the soil-moisture curves show, the permanent wilting percentage was reached a few days before June 7 . After that 
date, the marked differences in average size of the fruit reflect the severe soil-moisture conditions to which the trees in the dry plot were subjected. The thorough irrigation given to the dry plot shortly after July 19, after a relatively long period when the soil moisture had remained

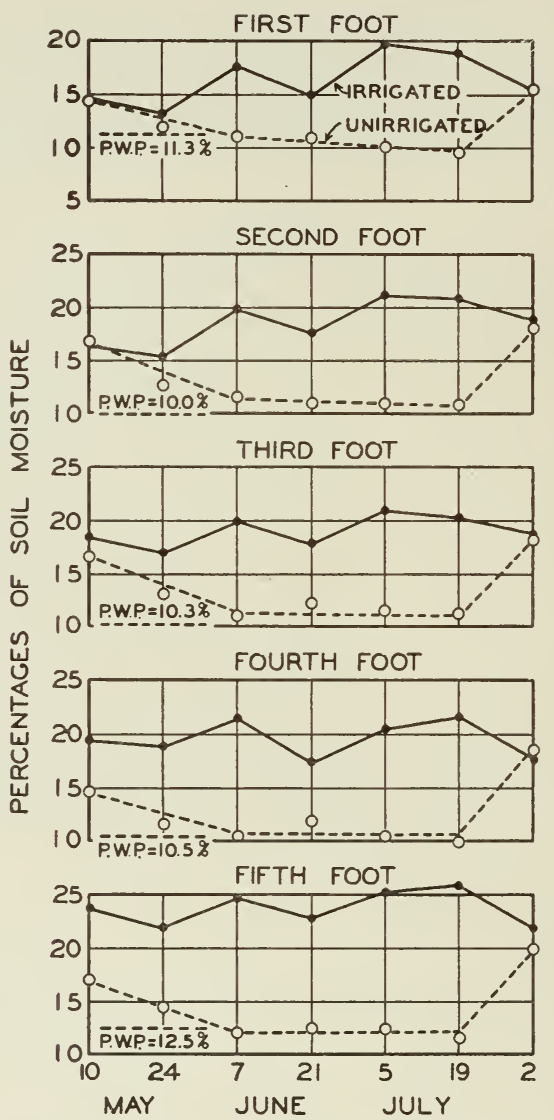

Fig. 9.-Soil-moisture conditions in the Prost orchard, Concord, 1939. The permanent wilting percentage is indicated by the letters P.W.P. The wet plot was irrigated June 1 and June 22, and the dry one, July 19.

at the permanent wilting percentage, increased the size of fruit in the dry plot.

The pressure tests of the fruit picked on July 26 showed 17.7 pounds for the wet plot, 19.6 pounds for the dry. After the usual period in cold storage, the fruit was allowed to ripen at a temperature between $65^{\circ}$ and $70^{\circ} \mathrm{F}$. The differences in hardness tended to disappear as the fruit matured, and on August 7 both lots were eating-ripe, approximately equal in quality and firmness. 
In preliminary trials in this orchard in 1938, similar results were obtained on the maturity of pears. The soil moisture was reduced to about the permanent wilting percentage in the dry plot on July 14, 1938, in the top 5 feet. The pears from the dry plot yielded a pressure test of 23.1 pounds on July 19, whereas those from the irrigated plot gave a test of 21.9. The average test for the entire picking season was 21.1 pounds for the dry plot, 20.5 for the wet.

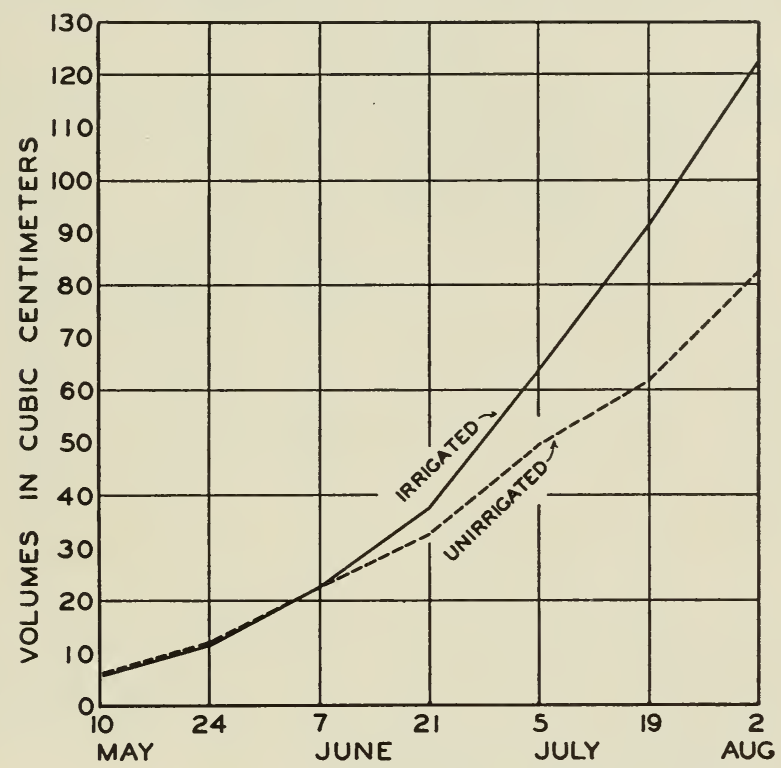

Fig. 10.-Sizes of pears in the Prost orchard, 1939.

\section{OBSERVATIONS ON MATURITY OF PEAR FRUITS UNDER DRY SOIL CONDITIONS IN OTHER DISTRICTS}

Besides the experiments previously described, soil-moisture studies on the maturity of pears, as measured by the pressure test, were conducted in several pear-growing districts in the Sacramento Valley and the Sierra Nevada foothills in 1939 and 1940. The soil samples were taken, just before and during the picking season, from irrigated and unirrigated plots. The soil types ranged from the fine silt of the Sacramento Delta region to the coarse-textured soils of the Holland and Sierra series, and to the red clay loam of the Aiken series at about 3,000 feet elevation. In the orchards where the trees in the dry plots exhausted the readily available moisture a week or more before picking time, the fruit was 1 to $2 \frac{1}{2}$ pounds harder than that from the irrigated trees. The data on the maturity of the fruit from these orchards substantiated those from the orchards previously described. 


\section{RESULTS WITH APPLES}

Hotle Orchard.-The Gravenstein apple trees in the Hotle orchard in the Gold Ridge district west of Sebastopol were mature productive trees about twenty years old, planted 30 feet apart. Because the irrigation water had to be procured from a domestic supply, only two trees were used in each plot. The soil, classed as a Gold Ridge sandy loam, was gen-

\section{TABLE 13}

Moisture Equivalents and Permanent Wilting Percentages of Gold Ridge Fine Sandy Loam Soll from the

Hotle Orchard, Sebastopol

\begin{tabular}{|c|c|c|c|}
\hline Depth & $\begin{array}{c}\text { Moisture } \\
\text { equivalent } \\
\text { (M.E.) }\end{array}$ & $\begin{array}{c}\text { Permanent } \\
\text { wilting } \\
\text { percentage } \\
\text { (P.W.P.) }\end{array}$ & $\frac{\text { M.E. }}{\text { P.W.P. }}$ \\
\hline $\begin{array}{l}\text { feet } \\
0 \text { to } 1 \ldots \ldots \ldots \ldots .\end{array}$ & $\begin{array}{l}\text { per cent } \\
10.0\end{array}$ & $\begin{array}{c}\text { per cent } \\
3.3\end{array}$ & $\begin{array}{l}\text { ratio } \\
3.03\end{array}$ \\
\hline 1 to $2 \ldots$. & 10.0 & 3.0 & 3.33 \\
\hline 2 to $3 \ldots$ & 10.3 & 2.9 & 3.55 \\
\hline 3 to $4 \ldots$ & 16.2 & 8.9 & 1.82 \\
\hline 4 to $5 \ldots$ & 22.2 & 10.7 & 2.07 \\
\hline 5 to $6 \ldots$ & 20.3 & 10.2 & 1.99 \\
\hline
\end{tabular}

erally considered the best apple soil in the district. This orchard was located in a district of heavy winter rainfall and comparatively cool conditions during the growing season, with some early morning fogs. The annual rainfall was about 30 inches.

Experiments were carried out in 1930 by Mr. B. B. Burlingame, a graduate student, with Gravenstein apples in the Hotle orchard in the Sebastopol district. Table 13 gives the water-holding properties of the soil, figure 11 the soil-moisture record for the 1930 season. The orchard was located on hilly land; and the soil, apparently, was not uniform over the area sampled for moisture determinations.

On May 27, when the first set of samples was taken, the soil moisture in the top 6 feet was at or slightly below the moisture equivalent. Several heavy rains during April and May were probably the reason why extraction of moisture from the soil had been slow during these months. Extraction of moisture in the top 3 feet was about the same in the two plots until July 5. The wet plot was irrigated on July 11, the water penetrating to a depth of about 6 feet. After July 12, the extraction in the top 3 feet of the dry plot almost ceased. At all times during the growing season, apparently, there was an ample supply of readily available moisture below 3 feet. 
Figure 12 shows the growth of the fruit. The average size of the measured apples was slightly greater in the dry plot than in the wet at the beginning of the season and remained so until harvest.
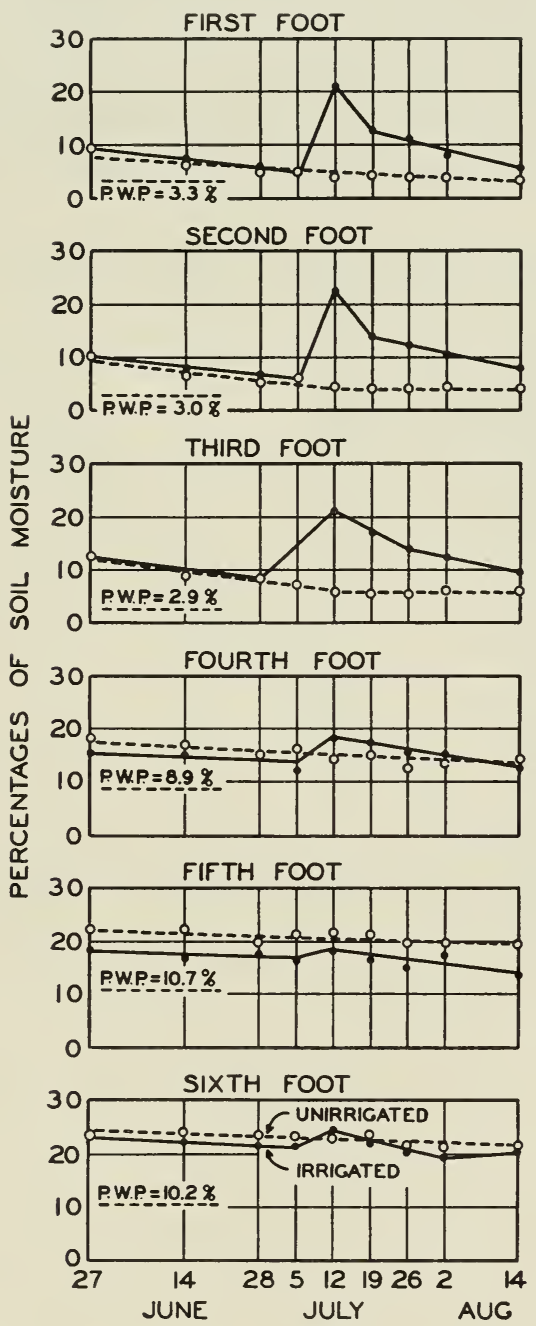

Fig. 11.-Soil-moisture conditions in the Hotle orchard, Sebastopol, 1930. The permanent wilting percentage is indicated by the letters P.W.P. The wet plot was irrigated July 11.

The readily available moisture in the top 3 feet of soil was exhausted about the middle of July. The soil moisture contents at this time agreed closely with the permanent wilting percentages obtained from the stock supply of soil from the top 2 feet. In the third foot, however, 
the agreement was not close, probably because of the inclusions of the fine-textured soil in the samples taken for the moisture determinations. These inclusions were unavoidable because of the undulating surface of the fine-textured layer in the fourth foot. The fruit in the dry plot began to grow more slowly than that in the wet one after July 19.

Jerenich Orchard.-The apple trees in the A. N. Jerenich orchard at Watsonville were of the Yellow Newtown variety, about twenty-five years old, vigorous, uniform, and exceptionally productive. They were planted

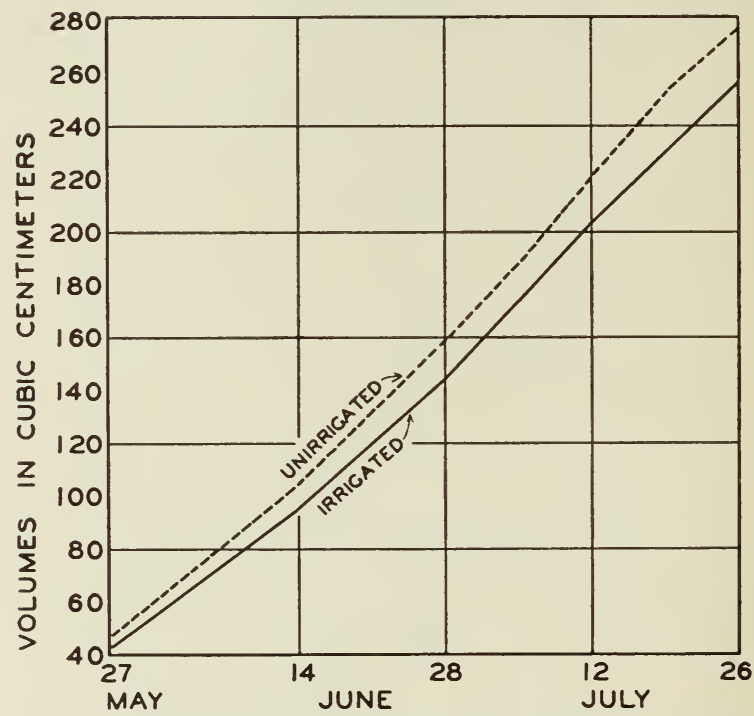

Fig. 12.-Sizes of apples in the Hotle orchard, 1930.

30 feet apart on the square system. The plots consisted of four trees each, with the customary guard rows around each plot. The soil was classified as a Pajaro loam. There was difficulty in interpreting the soil-moisture conditions, probably because of the gravel present in the top 4 feet and abrupt changes in texture in the lower depths. The district is characterized by fairly heavy rainfall during the winter and mild to cool weather during much of the growing season. Soil drainage was good to a depth of 12 feet.

Experiments with Yellow Newtown apples in the Jerenich orchard were started in 1932, but discontinued after one year because gravel in the soil made it difficult to obtain a satisfactory soil-moisture record. Table 14 gives the water-holding properties of this soil. As shown by the soil-moisture record for the Jerenich orchard in 1932 (fig. 13), however, the use of water by apple trees is less rapid in the relatively cool coastal 
climate than it is for pears in the warm interior climates. This fact is important. The slight downward slope of the curves from the dry plot, particularly in the top 3 feet, indicates very slow extraction of moisture. The permanent wilting percentage was not reached during the growing season except in the top foot. Water was applied to the wet plot on June 15 and on August 18, the former penetrating about 5, the latter more than 6 feet. Both plots had available soil moisture except in the top foot

TABLE 14

Moistiure Equivalents and Permanent Wilting Percentages of Pajaro Loam SoIL From the JERENICH

ORCHARD, WATSONVILLE

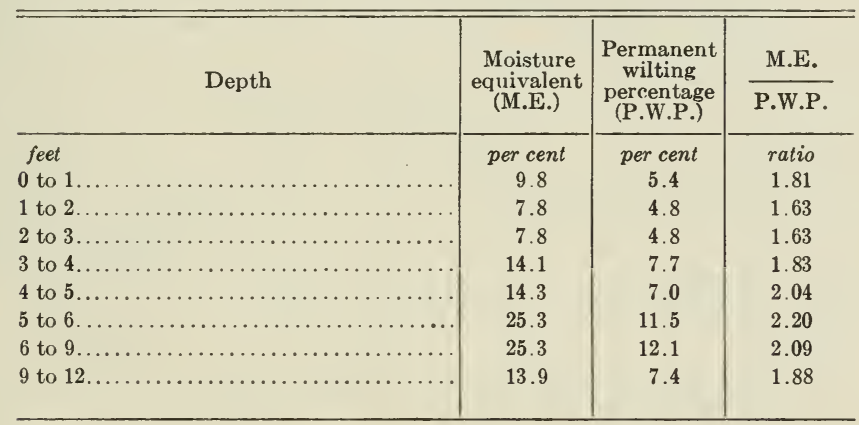

of the dry plot throughout the summer. There were no differences in the sizes of fruit (fig. 14) that could be attributed to the irrigation treatment.

Two boxes of fruit from each plot for storage tests were secured on September 5 and on September 20. The pressure tests indicated the same degree of maturity at picking time of the fruit from the two plots. The fruit was brought to Davis and stored at $36^{\circ} \mathrm{F}$. Pressure tests and observations on color and quality were made at monthly intervals during the winter. Early in May, when the fruit was removed from storage, all showed approximately the same color. There was no evidence of rot; and the apples were all in excellent condition except for internal browning, which was about the same in all lots.

Rowe Orchard.--In 1933 the experimental work with apples was transferred to the J. H. Rowe orchard about 5 miles southeast of Watsonville, where it was continued for two years. The trees in the Rowe orchard were of the Yellow Newtown variety, about thirty years old at the time of the experiment, planted 30 feet apart and fairly uniform in size, with a long record of profitable production. The soil was classified as a Pajaro clay loam adobe. The top $21 / 2$ feet was typical adobe. Between $21 / 2$ and 4 feet was a compact layer of clay containing, apparently, fewer roots than the 


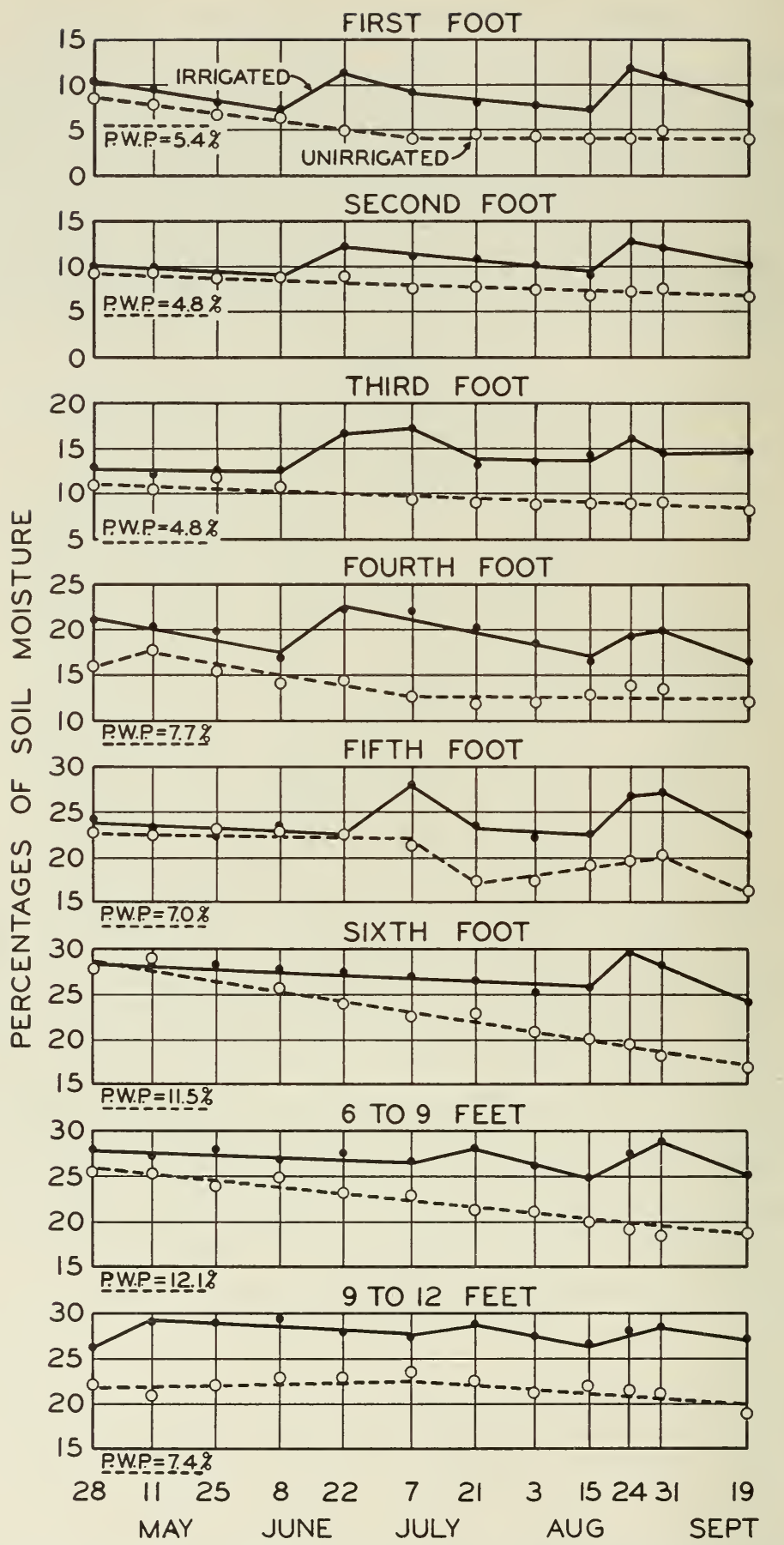

Fig. 13.- Soil-moisture conditions in the Jerenich orchard, Watsonville, 1932. The permanent wilting percentage is indicated by the letters P.W.P. The wet plot was irrigated June 15 and August 18. 
layer above it. Below 4 feet the soil was somewhat lighter in texture. Apparently the clay layer in the second and third feet did not seriously interfere with drainage. The climatic conditions resembled those de-

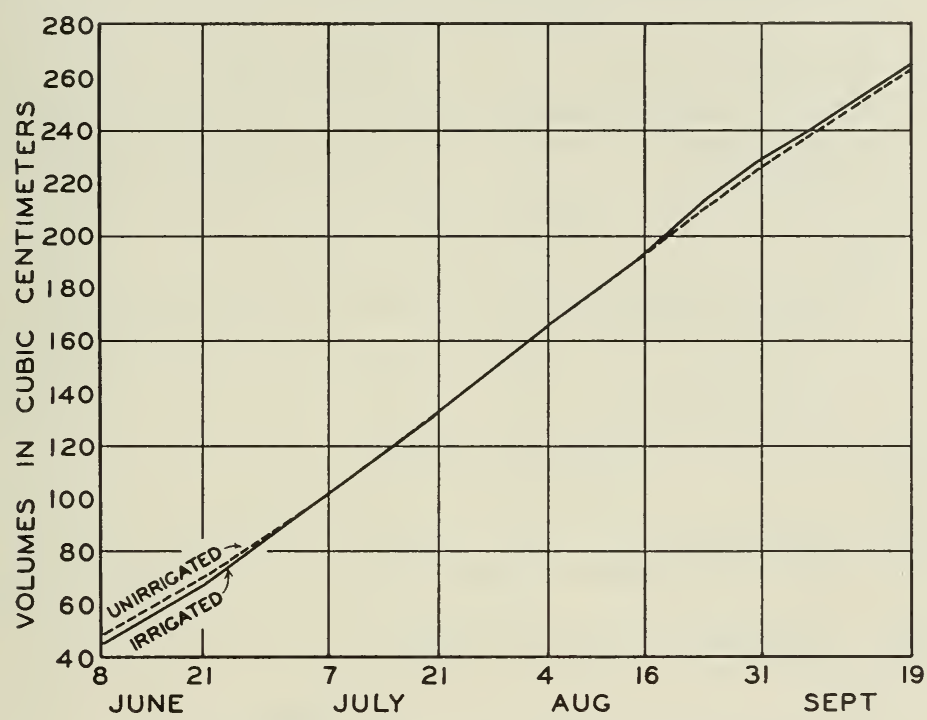

Fig. 14.--Sizes of apples in the Jerenich orchard, 1932.

TABLE 15

Moisture Equivalents and Permanent Wilting Percentages of Pajaro Clay Loam Soll Adobe From the Rowe

ORCHARD, WATSONVILLE

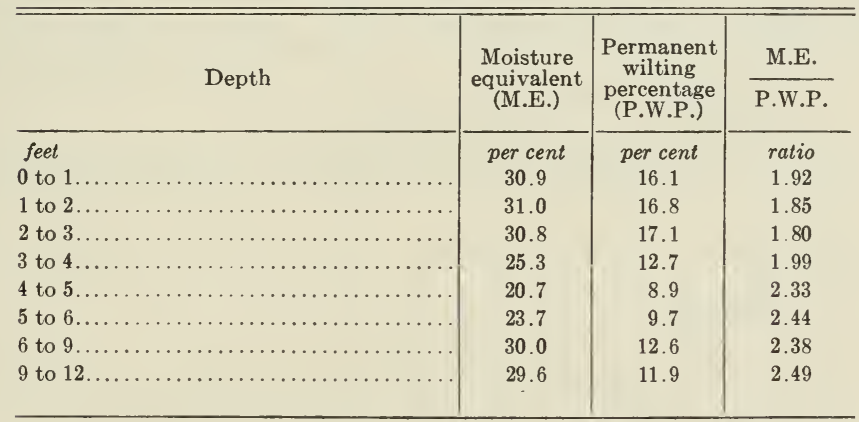

scribed for the Nutting and Jerenich orchards. The soil in this orchard had typical adobe characteristics and held a large amount of water at the moisture equivalent (table 15). In the top 4 feet, where apparently most of the roots were growing, about half of the moisture at field capacity was available for use by the trees. 


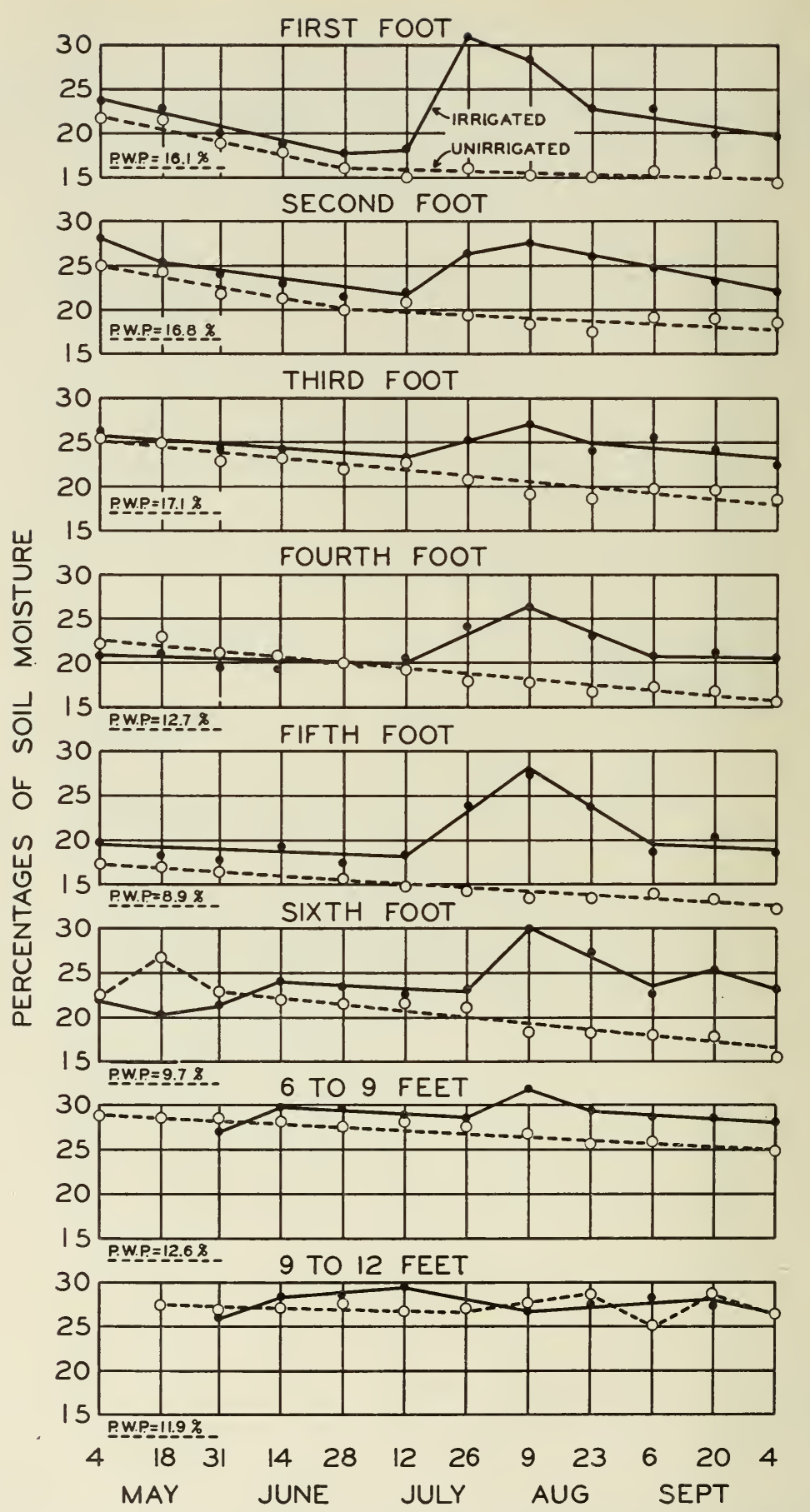

Fig. 15.- Soil-moisture conditions in the Rowe orchard, Watsonville, 1933. The permanent wilting percentage is indicated by the letters P.W.P. The wet plot was irrigated July 19. 
Figure 15 presents the soil-moisture record for 1933 . Water was used slowly. The permanent wilting percentage was reached only in the first foot. On June 28 the readily available moisture was exhausted in the top foot of the dry plot. The curves show slow extraction of moisture to a depth of about 6 feet. As shown by the records for the 6 -to-9- and the 9-to-12-foot depths, the soil moisture at these levels never got below about 25 per cent, which was but slightly below the moisture equivalent. The

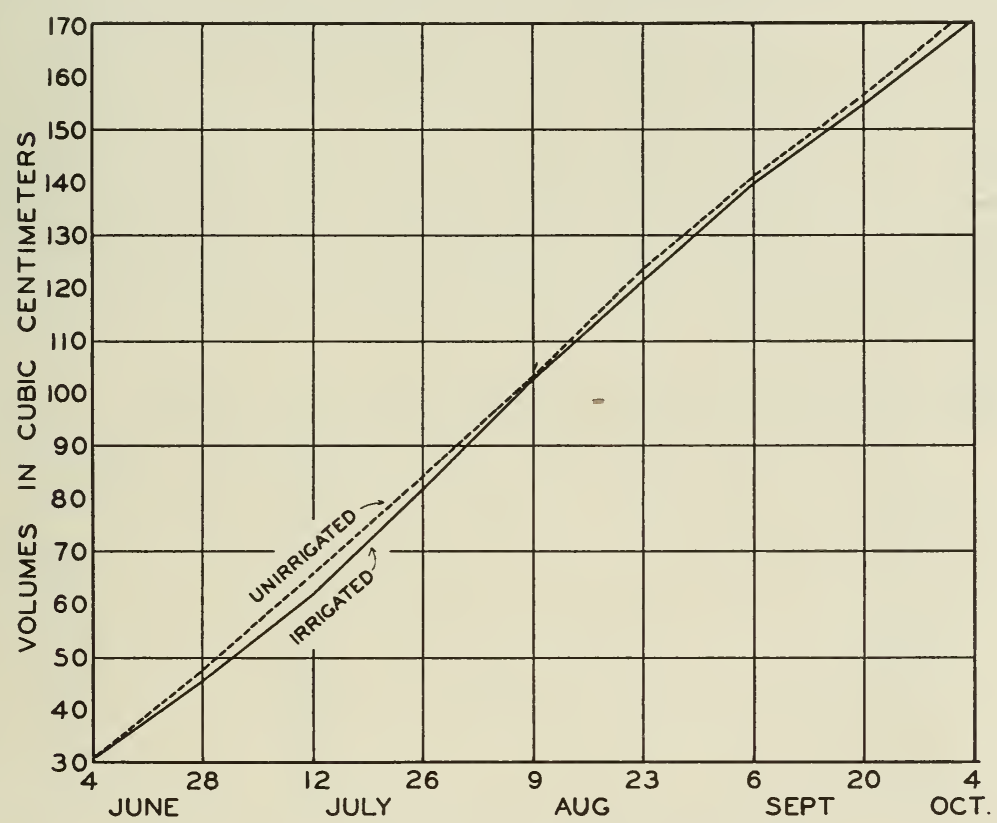

Fig. 16.--Sizes of apples in the Rowe orchard, 1933.

wet plot was irrigated on July 19, the water penetrating a little below 6 feet.

Figure 16 shows the sizes of the measured apples. Fruits from both plots grew at approximately the same rate throughout the growing season.

In 1934 the treatments of the plots were reversed, the 1933 dry plot becoming the wet one. The soil-moisture conditions in 1934 resembled those of 1933. Table 16 gives the soil-moisture percentages. The permanent wilting percentage was reached in the top foot on August 24 in the dry plot, but there was readily available moisture at the other depths throughout the growing season. Since the soil moisture at the 6-to-9-and 9-to-12-foot depths remained at approximately the field capacity all season, the records for them are not presented. 
TABLE 16

Average Soll-Moisture Percentages, Rowe Orchard, Watsonville, 1934

\begin{tabular}{|c|c|c|c|c|c|c|c|c|c|c|c|c|}
\hline \multirow{2}{*}{ Date } & \multicolumn{6}{|c|}{ Wet plot* } & \multicolumn{6}{|c|}{ Dry plot } \\
\hline & $\begin{array}{l}0-1 \\
\text { ft. }\end{array}$ & $\begin{array}{l}1-2 \\
\text { ft. }\end{array}$ & $\begin{array}{l}2-3 \\
\mathrm{ft} .\end{array}$ & $\begin{array}{l}3-4 \\
\mathrm{ft} .\end{array}$ & $\begin{array}{l}4-5 \\
\text { ft. }\end{array}$ & $\begin{array}{l}5-6 \\
\mathrm{ft} .\end{array}$ & $\begin{array}{l}0-1 \\
\mathrm{ft} .\end{array}$ & $\begin{array}{l}1-2 \\
\text { ft. }\end{array}$ & $\begin{array}{l}2-3 \\
\text { ft. }\end{array}$ & $\begin{array}{l}3-4 \\
\text { ft. }\end{array}$ & $\begin{array}{l}4-5 \\
\mathrm{ft} .\end{array}$ & $\begin{array}{l}5-6 \\
\text { ft. }\end{array}$ \\
\hline & $\begin{array}{c}\text { per } \\
\text { cent }\end{array}$ & $\begin{array}{c}p \epsilon r \\
\text { cent }\end{array}$ & $\underset{\text { cent }}{\text { per }}$ & $\begin{array}{c}\text { per } \\
\text { cent }\end{array}$ & $\begin{array}{c}\text { per } \\
\text { cent }\end{array}$ & $\begin{array}{c}\text { per } \\
\text { cent }\end{array}$ & $\begin{array}{c}\text { per } \\
\text { cent }\end{array}$ & $\begin{array}{c}\text { per } \\
\text { cent }\end{array}$ & $\begin{array}{c}\text { per } \\
\text { cent }\end{array}$ & $\begin{array}{c}\text { per } \\
\text { cent }\end{array}$ & $\begin{array}{c}\text { per } \\
\text { cent }\end{array}$ & $\begin{array}{c}\text { per } \\
\text { cent }\end{array}$ \\
\hline April 19. & 22.3 & 26.1 & 23.6 & 18.7 & 16.7 & 20.8 & 21.5 & 27.1 & 26.5 & 23.8 & 24.0 & 28.3 \\
\hline May 2. & 19.0 & 25.1 & 24.4 & 18.2 & 16.6 & 21.5 & 19.1 & 25.7 & 25.9 & 23.6 & 23.7 & 27.8 \\
\hline May 15. & 18.7 & 23.1 & 23.8 & 21.4 & 15.0 & 22.3 & 18.6 & 24.2 & 24.4 & 22.4 & 23.3 & 26.4 \\
\hline May $30 .$. & 17.5 & 21.3 & 22.8 & 20.7 & 17.4 & 20.5 & 18.7 & 22.7 & 23.6 & 19.9 & 21.4 & 23.4 \\
\hline June 11. & 19.3 & 21.6 & 23.1 & 19.2 & 18.1 & 22.8 & 19.3 & 22.5 & 23.3 & 20.4 & 21.3 & 26.2 \\
\hline June 27.. & 17.3 & 21.3 & 22.1 & 18.4 & 14.5 & 20.4 & - & - & 22.3 & 19.2 & 19.5 & 25.1 \\
\hline July $11 .$. & - & - & - & - & - & - & 17.6 & 21.5 & 21.8 & 19.3 & 17.1 & 21.4 \\
\hline July $26 .$. & 24.0 & 26.5 & 25.0 & 26.6 & 17.7 & 20.4 & 17.6 & 21.0 & 20.9 & 19.4 & 17.7 & 21.3 \\
\hline August 9. & 20.4 & 23.2 & 23.7 & 20.7 & 13.9 & 19.3 & 17.5 & 21.2 & 20.6 & 18.1 & 16.6 & 19.7 \\
\hline August 24 . & 18.9 & 21.5 & 23.6 & 21.0 & 16.0 & 20.4 & 15.7 & 20.3 & 20.9 & 16.4 & 15.1 & 18.8 \\
\hline September 1 & 18.1 & 20.3 & 22.1 & 19.5 & 15.3 & 20.3 & 15.3 & 19.9 & 19.2 & 14.8 & 14.9 & 17.4 \\
\hline
\end{tabular}

* Irrigated July 9, 1934.

The volumes of the measured fruits in 1934 were as follows :

\begin{tabular}{|c|c|c|}
\hline Date & $\begin{array}{l}\text { Volume, wet } \\
\text { plot, in cc }\end{array}$ & $\begin{array}{l}\text { Volume, dry } \\
\text { plot, in ce }\end{array}$ \\
\hline May 2. & . 6.5 & 9.0 \\
\hline May 15. & . . $\quad 17.2$ & 23.2 \\
\hline May $30 .$. & 36.1 & 48.4 \\
\hline June 12. & $\begin{array}{ll}\text {. } & 53.7\end{array}$ & 71.9 \\
\hline June 27. & 73.7 & 104.3 \\
\hline July 11.. & . . 100.0 & 132.2 \\
\hline July 26. . & . . 129.7 & 172.0 \\
\hline August 9 . & 156.1 & 203.8 \\
\hline August 23 & 184.3 & 239.1 \\
\hline
\end{tabular}

No differences that could be attributed to the irrigation treatment were obtained. Those in the dry plot were slightly larger than those in the wet at the beginning of the season, and possibly because of a light crop in the dry plot, grew faster than those in the wet and were considerably larger at picking time.

In both years, initial pressure tests were approximately equal.

Storage tests indicated essentially the same keeping qualities for the fruit from the two treatments. The fruit picked in $1933 \mathrm{kept}$ in good condition in $36^{\circ} \mathrm{F}$ storage until May 1, 1934. At that time the proportions of each lot showing internal browning and shriveling were approximately equal.

\section{DISCUSSION OF RESULTS}

One fact brought out in these experiments is the comparatively slow use of soil moisture by mature pear and apple trees in the central-coast region of California. This condition is shown in the soil-moisture records 
for the Nutting, Hotle, Jerenich, and Rowe orchards, where the permanent wilting percentages were not reached except in the first foot and in the Hotle orchard in the second and third feet. Tine soils in these orchards ranged from the fairly coarse soil in the Jeren ch orchard to the fine-textured soils in the Nutting and Rowe orchards. During years of normal rainfall, when the moisture penetrates to a depth of 6 feet or more, it is probable that irrigation is unnecessary under these conditions; and in years of deficient rainfall one or possibly two irrigations to a depth of 6 feet should suffice.

No responses in growth of the fruit obtained from the orchards in the coast region seemed to be associated with the irrigation treatment, and, as a rule, the measured fruits in both treatments grew at about the same rate throughout the season. Pressure tests from comparable lots showed no consistent differences, and keeping qualities were not affected. The rate of growth of the fruits during a given season was not influenced by the irrigation treatment in those experiments in which there was readily available moisture in both treatments in all but the surface layer during the growing season; yet the irrigated plots had higher soil-moisture contents than the unirrigated plots for considerable periods each year.

The experiments with pears from the University Farm orchard at Davis, from the Benson orchard in the Lake County pear district, from the Cleland orchard in Mendocino County, and from the Prost orchard in Contra Costa County gave results similar to those obtained with peaches, prunes, grapes, and walnuts. These four orchards are located in districts where the climatic conditions during the growing season are characterized by higher temperatures than those in the central-coast region. The climate at Davis is fairly typical of the interior valley of California, with a rainless period that generally extends from April or May until October, and with clear summer days with frequent maximum temperatures of $100^{\circ} \mathrm{F}$ or slightly above. In general, the climatic conditions in the orchards in Lake and Mendocino counties resemble those at Davis except that the winter rainfall is greater and the summer temperature slightly lower than at Davis. The days are generally cloudless and free from fog during the growing season. In these orchards the soil moisture usually reached the permanent wilting percentage in the top 4 to 6 feet late in June or early in July. On a few occasions unusual rainfall in June served to delay the time when the permanent wilting percentage was reached until later in the season.

In the Benson orchard in Lake County, the permanent wilting percentage was reached about July 9 in 1935 in the top 4 feet, as indicated by the flattening of the soil-moisture curves. The exhaustion of readily available soil moisture was accompanied by a slowing down in the growth 
of the fruit. Fruit growth behaved similarly in 1936 and 1937 when the readily availàile soil moisture was exhausted. Clearly, decrease in the rate of growth of fruit in the Cleland orchard in Mendocino County occurs about the time when the permanent wilting percentage is reached (tables 7,8 , and figs. 5, 6). The readily available soil moisture in the dry plot in the University Farm orchard was depleted during the first week in August, and the fruit grew more slowly. In the Prost orchard in Contra Costa County, the permanent wilting percentage in the dry plot was reached early in June, because of a deficient winter rainfall, and the growth of the fruit was retarded at about the same time. Thus, similar results were secured from both medium-textured (Yolo series) and finetextured soils (Dublin and Zamora series) in three widely separated pear districts.

The maturity of pears as measured by the pressure test was retarded in the dry plots of the orchards from the interior region, but not in the coast region. In general, if the available soil moisture was exhausted a considerable period before harvest, the pressure tests of the pears from the dry plots were considerably higher than for the fruit from the wet. On the other hand, if readily available moisture was present until shortly before picking, little or no difference was found in the pressure tests of the fruits from the two treatments. These results may help to explain why pears in certain unirrigated sections ripen comparatively late, whereas other fruits like apricots, plums, and peaches, which mature before the soil moisture from the winter rains is exhausted, do not have their ripening season affected.

As the storage tests revealed, the differences in maturity of pears, because of the irrigation treatment, tended to disappear in storage and both lots matured at the same time. When eating-ripe, the pears from both treatments had approximately the same pressure test; and various observers who tried them could detect no marked differences in quality.

The soil-moisture and the growth records indicate that one or two irrigations before harvest in a normal year, wetting the soil to a depth of 6 feet, will suffice to maintain readily available moisture until after harvest in pear orchards in Lake, Mendocino, Contra Costa, and Yolo counties under conditions like those in the experimental plots. Though an additional watering may be desirable after harvest, the experiments were not continued long enough to secure evidence on this question. If only one or two irrigations are necessary before harvest, conflicts between irrigation practice and the spraying program may easily be avoided. The evidence, using the increase in volumes of pears as a criterion, shows that the availability of water did not decrease until the soil moisture was reduced close to the permanent wilting percentage. 


\section{CONCLUSIONS}

In the central-coast region in years of normal rainfall, pear and apple trees on medium- or fine-textured soils similar to those reported in this bulletin do not exhaust the readily available moisture until late in the season. Under these conditions, irrigation seems unnecessary.

Mature pear orchards in districts where the climatic conditions somewhat resemble those of the interior valley, such as Lake, Mendocino, and Contra Costa counties, exhaust the soil moisture to the permanent wilting percentage in the top 4 to 6 feet of soil about the last week in June or the first week in July during normal years. Under these conditions, the trees, if growing on soil at least 6 feet deep, may be kept supplied with readily available water with one or two irrigations before harvest.

When the readily available soil moisture is exhausted, the pears slow down in growth on both medium- and fine-textured soils. But when the permanent wilting percentage is not reached while the fruit is on the trees, the growth of the fruit is not retarded.

The apple experiments were conducted under mild climatic conditions. Under these conditions when the readily available soil moisture below the first foot is exhausted, the apples slow down in growth, but when the permanent wilting percentage is not reached, the growth of the fruit is not retarded.

The maturity of pears (as measured by the pressure test) is delayed if the readily available soil moisture is exhausted a week or more before the normal harvest period. Differences in maturity between fruit from the irrigated and from the unirrigated plots tend to disappear in storage.

According to these experiments, pears grow normally under a wide range of soil and climatic conditions when the trees are kept supplied with readily available soil moisture, but deleterious responses result when the soil moisture is reduced to about the permanent wilting percentage during the growing season. These responses are generally shown by decreased size and delayed maturity. 
1. ALDRICH, W. W.

\section{LITERATURE CITED}

1937. Six years' study of pear irrigation. Oregon State Hort. Soc. Proc. 29: $79-87$.

2. Aldrich, W. W., AND ARCH Work.

1933. Preliminary report of pear tree responses to variations in available soil moisture in clay adobe soil. Amer. Soc. Hort. Sci. Proc. 29:181-87.

3. ALDRICH, W. W., AND R. A. WORK.

1934. Effect of leaf-fruit ratio and available soil moisture in heavy clay soil upon amount of bloom of pear trees. Amer. Soc. Hort. Sci. Proc. 31:57-74.

4. AldRICH, W. W., AND R. A. Work.

1935. Evaporating power of the air and top-root ratio in relation to pear fruit enlargement. Amer. Soc. Hort. Sci. Proc. 32:115-23.

5. AldRich, W. W., R. A. Work, AND M. R. LEWis.

1935. Pear root concentration in relation to soil moisture extraction in heavy clay soil. Jour. Agr. Res. 50:975-88.

6. Bornton, DAMON.

1937. Soil moisture and fruit growth in an orchard situated on shallow soil in the Hudson Valley, N. Y. Amer. Soc. Hort. Sci. Proc. 34:169-72.

7. Furr, J. R., AND E. S. Degman.

1932. Relation of moisture supply to stomatal behavior of the apple. Amer. Soc. Hort. Sci. Proc. 28:547-51.

8. Furr, J. R., ANd J. R. Magness.

1931. Preliminary report on relation of soil moisture to stomatal activity and fruit growth of apples. Amer. Soc. Hort. Sei. Proc. 27:212-18.

9. HALler, M. H., AND P. L. HARDiNG.

1938. Relation of soil moisture to firmness and storage quality of apples. Amer. Soc. Hort. Sci. Proc. 35:205-11.

10. Hendrickson, A. H., ANd F. J. Veihmeyer.

1929. Irrigation experiments with peaches in California. California Agr. Exp. Sta. Bul. 479:1-63.

11. Hendrickson, A. H., And F. J. Veihmeyer.

1934. Irrigation experiments with prunes. California Agr. Exp. Sta. Bul. 573: $1-44$.

12. HeNDRICKson, A. H., AND F. J. VeiHMEYER.

1937. The irrigation of pears on a clay adobe soil. Amer. Soc. Hort. Sci. Proc. 34:224-26.

13. Lewis, M. R., R. A. Work, AND W. W. AldRICH.

1934. Studies of the irrigation of pear orchards on heavy soil near Medford, Oregon. U. S. Dept. Agr. Tech. Bul. 432:1-33.

14. Lewis, M. R., R. A. Work, AND W. W. AldRICH.

1935. Influence of different quantities of moisture in a heavy soil on rate of growth of pears. Plant Physiol. 10:309-23.

15. Magness, J. R., E. S. Degman, ANd J. R. Furr.

1935. Soil moisture and irrigation investigations in eastern apple orchards. U. S. Dept. Agr. Tech. Bul. 491:1-36. 
16. RYall, A. L., AND W. W. ALDRICH.

1938. The effects of water supply to the tree upon water content, pressure test, and quality of Bartlett pears. Amer. Soc. Hort. Sci. Proc. 35:283-88.

17. RYALL, A. L., AND F. C. ReImer.

1937. The effects of water supply to the tree upon storage and dessert quality of Anjou pears grown in clay adobe soil in the Rogue River Valley. Oregon State Hort. Soc. Proc. 29:74-78.

18. VeIHMEYER, F. J., AND A. H. HENDRICKSON.

1936. Essentials of irrigation and cultivation of orchards. California Agr. Ext. Cir. 50:1-24.

19. Veihmeyer, F. J., AND A. H. Hendrickson.

1938. Soil moisture as an indication of root distribution in deciduous orchards. Plant Physiol. 13:169-77.

20. WorK, R. A.

1937. The control of soil moisture. Oregon State Hort. Soc. Proc. 29:41-46.

21. Work, R. A., AND M. R. LEwIS.

1936. The relation of soil moisture to pear tree wilting in a heavy clay soil. Amer. Soc. Agron. Jour. 28 :124-34. 
